\title{
TITLE:
}

\section{CUMACEAN CRUSTACEA FROM AKKESHI BAY, HOKKAIDO}

AUTHOR(S):

Gamo, Sigeo

CITATION:

Gamo, Sigeo. CUMACEAN CRUSTACEA FROM AKKESHI BAY, HOKKAIDO. PUBLICATIONS OF THE SETO MARINE BIOLOGICAL LABORATORY 1965, 13(3): 187-219

ISSUE DATE:

1965-10-30

URL:

http://hdl.handle.net/2433/175407

RIGHT: 


\title{
CUMACEAN CRUSTACEA FROM AKKESHI BAY, HOKKAIDO ${ }^{1)}$
}

\section{SIGEO GAMÔ}

\author{
Faculty of Liberal Arts and Education, Yokohama \\ National University, Kamakura, Kanagawa-Ken
}

\section{With 12 Text-figures}

Our knowledge of the Cumacea of Hokkaido and its adjacent waters is due to the contributions of Derzhavin (1923, 1926), Uéno (1933, 1936), Zimmer (1929, 1939, 1940, 1943) and Lomakina (1955 a-b; $1958 \mathrm{a}-\mathrm{b})$.

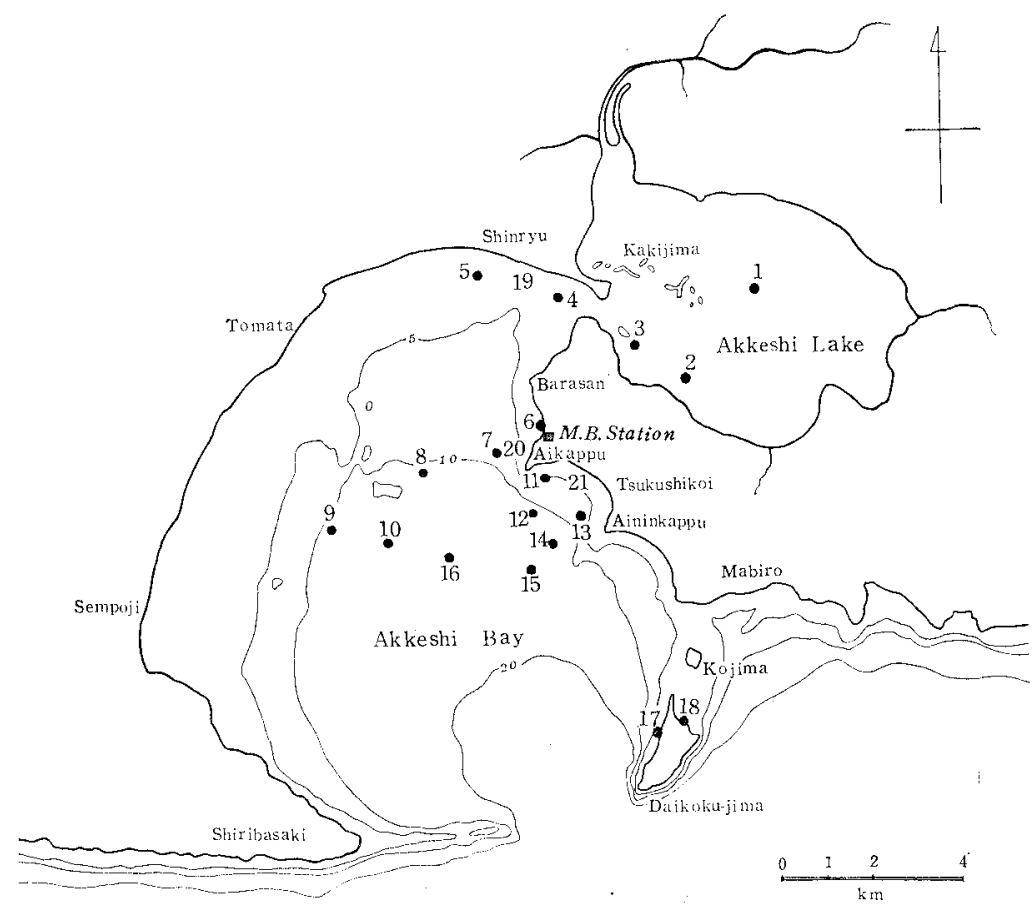

Fig. 1. Map of Akkeshi Bay. Solid circles with numbers indicate the stations where the cumaceans were collected by the Ekman-Berge bottom-sampling grab, 19-21 show the places where the subsurface towing of plankton-net was made at night.

1) Contributions from the Akkeshi Marine Biological Station, No. 126.

Publ. Seto Mar, Biol, Lab., XIII (3), 187-219, $1965 . \quad$ (Article 10) 
Table 1. Occurrence of cumaceans in Akkeshi Bay.

\begin{tabular}{|c|c|c|c|c|c|c|c|c|c|c|c|c|c|c|c|c|c|c|c|c|}
\hline Station number & 1 & 2 & 3 & 4 & 5 & 6 & 7 & 8 & 9 & 10 & $11 \sim 12$ & 13 & 14 & 15 & 16 & 17 & 18 & 19 & 20 & 21 \\
\hline $\operatorname{Depth}(\mathrm{m})$ & 2 & 1 & 3 & 8 & 2 & 0.3 & 9 & 11 & 11 & 14 & $8 \sim 12$ & 6 & 13 & 14 & 15 & 0.3 & 0.3 & \multirow{2}{*}{\multicolumn{3}{|c|}{$\begin{array}{l}\text { night } \\
\text { surface } \\
\text { tow-net }\end{array}$}} \\
\hline Bottom character & M & M & M & M & $\mathrm{S}$ & fS & M & M & $\mathbf{M}$ & $\mathrm{sM}$ & $S$ and $M$ & $\mathrm{~S}$ & $\mathbf{M}$ & $\mathrm{S}$ & $\mathbf{M}$ & $\mathrm{S}$ & $\mathrm{S}$ & & & \\
\hline \multicolumn{21}{|l|}{$\begin{array}{l}\text { Species of cumaceans } \\
\text { Bodotriidae }\end{array}$} \\
\hline Bodotria ovalis & - & - & - & - & - & - & - & - & - & - & + & - & + & - & - & - & - & - & + & + \\
\hline B. serrulata & - & - & - & - & - & - & - & - & - & - & + & - & - & - & - & - & - & - & + & - \\
\hline \multicolumn{21}{|l|}{ Nannastacidae } \\
\hline Cumella sp. & + & + & - & - & - & + & - & - & - & - & - & - & - & - & - & - & - & - & - & - \\
\hline C. quadrispinosa & - & + & + & - & - & - & - & - & - & - & -- & - & - & - & - & - & - & - & - & - \\
\hline \multicolumn{21}{|l|}{ Lampropidae } \\
\hline Lamprops quadrispinosa longispina & - & - & - & - & - & - & - & - & - & - & - & - & - & - & - & - & - & + & + & + \\
\hline L. sarsi & - & - & - & - & - & + & - & - & - & + & - & - & - & - & - & - & - & + & + & + \\
\hline \multicolumn{21}{|l|}{ Diastylidae } \\
\hline Diastylis alaskensis & - & - & - & - & - & $\rightarrow$ & - & + & - & + & - & - & - & + & - & - & - & - & + & + \\
\hline D. lazarevi & - & - & - & - & - & - & - & - & - & - & - & - & - & - & - & - & - & + & - & + \\
\hline Diastylopsis dawsoni forma calmani & - & + & + & + & + & - & + & + & + & + & + & + & + & + & + & - & - & + & + & + \\
\hline Dimorphostylis asiatica & - & + & + & - & - & + & - & - & - & + & - & - & - & - & - & $\rightarrow$ & - & + & + & + \\
\hline
\end{tabular}


The collection of the Cumacea dealt with in this paper was made by myself at the Akkeshi Marine Biological Station of Hokkaido University during the 16th to 20th of August 1963. The specimens were collected by Ekman-Berge bottom-sampling grab and also by subsurface towing of a plankton-net at night (Fig. 1 and Table 1). There were found ten species, of which three, Bodotria ovalis, B. serrulata and Cumella quadrispinosa were proposed as new to science in the previous paper (GAMÓ 1965). No cumaceans were collected at Stations 17 and 18 , on about $0.3 \mathrm{~m}$ deep rocky floor with seaweeds and covered with a thin layer of sand. A reduction in number of species and also of individuals occurred in the north-western inshore part of Akkeshi Bay and in Akkeshi Lake. This may be partly related to the low salinity and the shallowness of these regions. Contrarily an increase in number of species and of individuals was seen towards off Tsukushikoi, in the south eastern part of the Bay.

Five cold-water species, Lamprops quadriplicata longispina, L. sarsi, Diastylis alaskensis, D. lazarevi and Diastylopsis dawsoni forma calmani and a sigle warm water species, Dimorphostylis asiatica were included in the collection. Unfortunately, however, Leucon, Pseudoleucon and Eudorella of the family Leuconidae, expected in the surveyed area, were not represented in my collection.

Before going further I wish to acknowledge my indebtedness to Prof. Tune SAKAI for his kind guidance. I must express my gratitude to Prof. Huzio Utinomi of the Seto Marine Biological Laboratory and to Prof. Masao IwASA of the Seikei University for their invaluable advice. Further I wish to express my hearty thanks to Prof. Atsuhiko IchIKawa and Prof. Mayumi YAMADA of the Hokkaido University for their kindness in giving me an opportunity of performing the study. Also my thanks are due to Dr. Fumio Iwata and Mr. Zen NAGAO, marine zoologists of the Akkeshi Marine Biological Station, and to other members of the staff of the Station for their kind help in collecting the material.

\section{Description of the Species}

Family Nannastacidae

\section{Cumella sp.}

In juvenile female specimens, about $2.1 \mathrm{~mm}$ long, general features are somewhat like those of the juvenile male of Cumella sp. (C. rigida) from Tanabe Bay on the coast of Kii Peninsula (GAMO 1962). It differs from the adult female of $C$. rigida from Amami-Oshima Island (GAMÔ 1963) in having the carapace with acute antero-lateral corners and in that the postero-dorsal and dorso-lateral portions of the carapace are less compressed. 
In the manca larva about $1.2 \mathrm{~mm}$ long, the carapace is much inflated and the postero-dorsal and dorso-median portions are slightly compressed.

As all the specimens taken from Akkeshi Bay are juveniles, exact specific identification is impossible.

Material : 1 manca larva; St. 1, depth 2 m, muddy bottom ; Aug. 19, 1963. 1 manca larva ; St. 2, depth about $1 \mathrm{~m}$, muddy bottom; Aug. 18, 1963. 8 \% (juvenile); St. 6, fine sandy bottom, about $0.3 \mathrm{~m}$ below low water level; Aug. 19, 1963.

\section{Family Lampropidae}

\section{Lamprops quadriplicata longispina LOMAKINA}

(Figs. 2-4)

Lamprops quadriplicata longispina LOMAKINA 1958b, p. 85, fig. 32 .

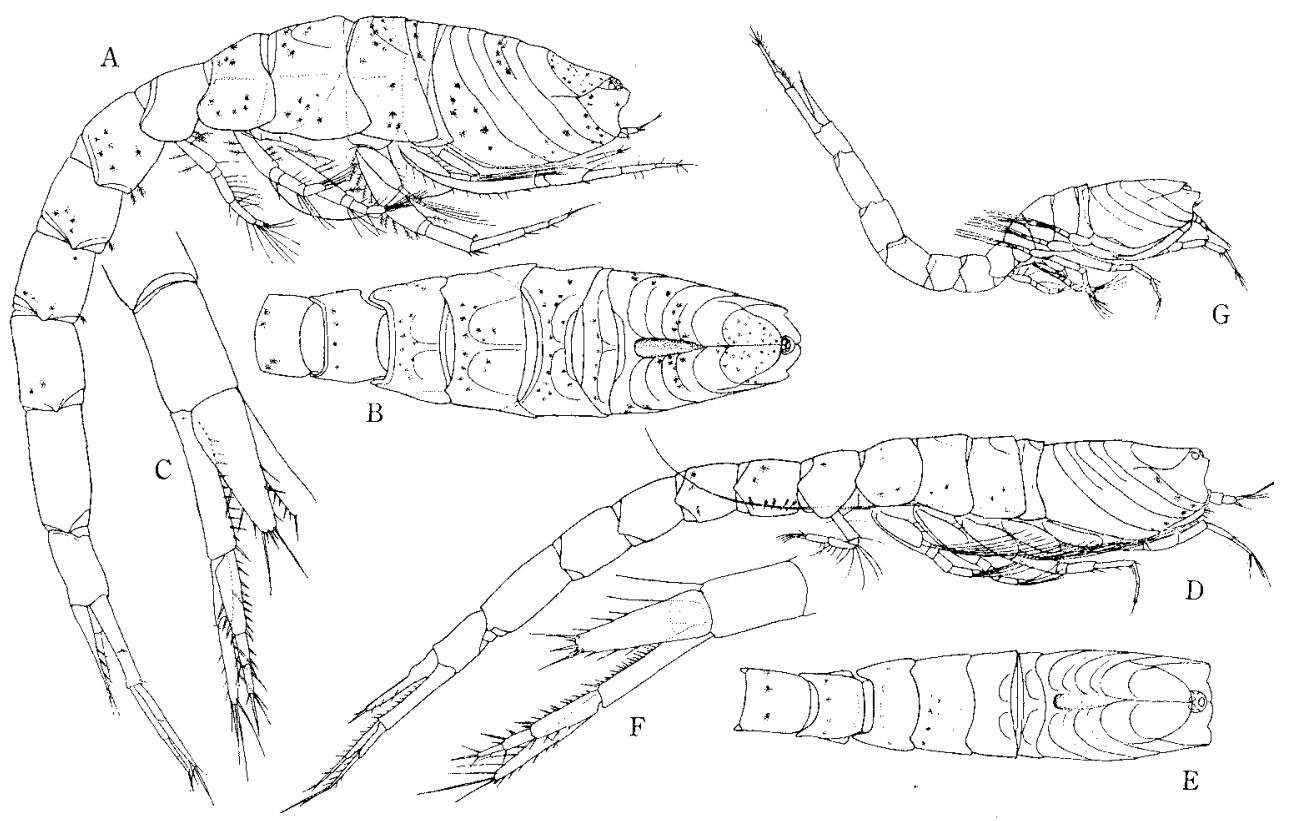

Fig. 2. Lamprops quadriplicata longispina Lomakina. Adult female with empty marsupium (length, ca. $6.8 \mathrm{~mm}$ ) : A : lateral view. B : anterior portion of body, from above. C : uropod with last abdominal segment. Adult male (length, ca. $5.5 \mathrm{~mm}$ ): D : lateral view. E : anterior portion of body, from above. F : uropod with last abdominal segment. G : young male (length, ca. $3.2 \mathrm{~mm}$ ).

Adult female with empty marsupium (length, about $6.8 \mathrm{~mm}$ ): The integument is thin, transparent and beset with many chromatophores. As seen from the side, the carapace has four transverse oblique lateral ridges, which are almost parallel with one another with about equal intervals. Each of the ridges 
leaves bakward from the dorso-median carina and then curves forward, in the course of the lateral surface of the carapace it runs obliquely forwards and downwards onto the lower margin of the carapace. A short oblique ridge is on each of the intermediate spaces between the last three ridges. On the anterior dorsal portion of the frontal lobe and the antero-lateral side of the carapace no ridges are found. The dorso-median carina is well-marked on the anterior portion; the hind portion of the carina becomes doubled by a shallow longitudinal furrow. The length of the carapace is nearly one-fifth of the total length of the animal and slightly more than one and one-third times the width, which is a little more than the depth. The antennal notch is shallowly concave, but distinct. The ocular lobe is round.

The combined length of all the free thoracic segments is less than one and two-thirds as long as the carapace. The first three segments are slightly wider than the carapace. On the dorsal surface of the first four segments there are a pair of semi-circular ridges.

The abdomen is a little longer than the cephalothorax. The first three segments are almost of the same size. The fourth segment is a little longer than the preceding one. The fifth segment is nearly one and one-fourth the length of the fourth one. The sixth segment is two-thirds as long as the fifth.

The first segment of the peduncle of the antennule is longer than the second, which is a little more than the length of the third. The main flagellum is long, more than the length of the third peduncular segment, threesegmented and bears two subequal aesthetascs. The accessory flagellum is rather large, almost reaches the end of the first segment of the main flagellum and three-segmented.

The rudimentary antenna is rather large and bears three segments.

The basis of the third maxilliped is less than twice as long as the remaining distal segments together and with plumose setae on the inner border and five hairs on the outer border.

The basis of the first peraeopod is long and slender, one and one-seventh as long as the remaining distal segments together, and fringed with plumose setae on the inner border; the distal part of the inner border with several plumose spines. The ischium is rather short. The merus, carpus and propodus are almost subequal in length. The dactylus is about three-fourths as long as the propodus and provided with unequal long spines, of which the longest one much exceeds the length of the segment.

The second peraeopod is five-sixths of the length of the first peraeopod and bears plumose spines on the inner border and spines at the distal end. The ischium is short. The merus is about three-fourths as long as the carpus which is much longer than the distal two segments combined. The dactylus is a little shorter than the propodus and with five spines at the distal end, of 


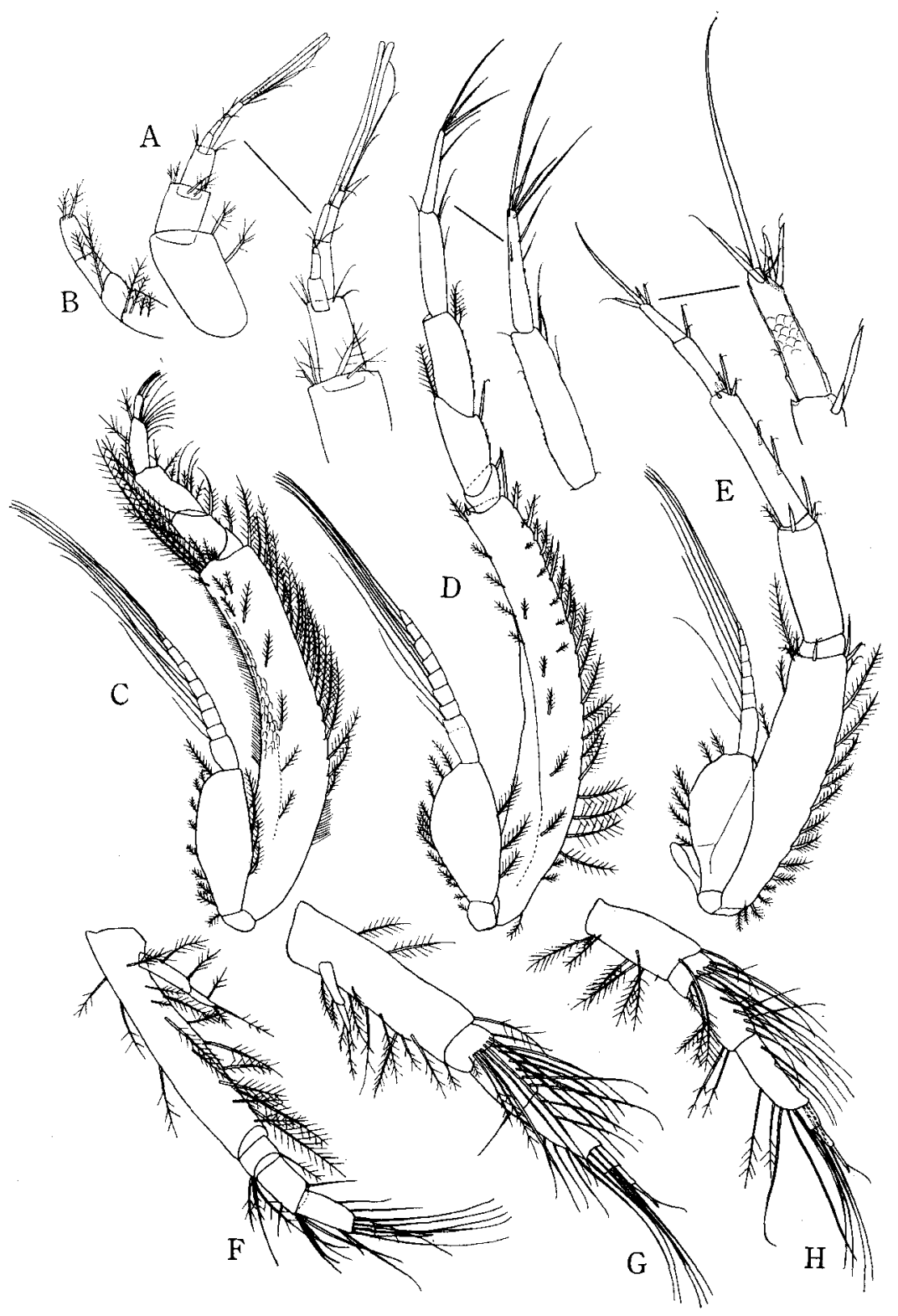

Fig. 3. Lamprops quadriplicata longispina LomAkINA. Adult female with empty marsupium : A : antennule. B : antenna. $\mathrm{C}$ : third maxilliped. $\mathrm{D}-\mathrm{H}:$ first to fifth peraeopods. 
which the longest one is nearly twice as long as the segment.

The basis of the third and fourth peraeopods is provided with a rudimentary exopod (Fig. 3, F-H).

The telson is one and one-fifth as long as the last abdominal segment, almost as long as the peduncular segment of the uropod and bears three pairs of lateral spines (the distal one is short and the proximal two rather long) and five apical spines (the outermost two are much more than one-third the length of the telson). The peduncle of the uropod is provided with eleven spines on the inner border. The endopod is a little less than the length of the peduncular segment and three-segmented; the proximal segment is more than one-half the length of the endopod, and one and one-third of the combined length of the subequal distal two segments and with nine spines on the inner and four on the distal part of the outer border; the third segment is provided with three unequal distal spines, of which the median one is longest and much exceeds the length of the segment. The exopod is slightly longer than the endopod and two-segmented; the proximal segment is a little shorter than the first segment of the endopod and with a spine on the inner border; the distal segment has four long spines on the inner, five spines on the outer border and two unequal long apical spines, one of which is a little less than the length of the distal segment.

Adult male (length, about $5.5 \mathrm{~mm}$ ): The pattern of the ridges on the carapace is very similar to that of the adult female. The length of the carapace is a little more than one-fifth of the total length of the animal and more than one and one-half of the width, which is a little more than the depth. The antennal notch is shallowly concave.

The combined length of all the free thoracic segments is nearly one and one-third the length of the carapace.

The abdomen is one-half of the total length of the animal. The first two segments are subequal in length. The third and fourth segments are slightly longer than the preceding ones. The fifth segment is one and one-third the length of the fourth one. The sixth is about two-thirds as long as the fifth.

The first segment of the peduncle of the antennule is slightly longer than the distal two segments together; the second is much more than the length of the third. The main flagellum is three-segmented. The accessory flagellum is rather large and two-segmented.

The flagellum of the antenna reaches the level of the middle of the fourth abdominal segment.

The basis of the third maxilliped is nearly twice as long as the remaining distal segments together.

The basis of the first peraeopod is one and one-fifth as long as the remaining distal segments together. The merus and carpus are subequal in 
length. The propodus is a little longer than the carpus. The dactylus is less than the length of the propodus and provided with spines on the distal end, of which the longest one much exceeds the length of the segment.

The second peraeopod is about six-sevenths of the length of the first peraeopod. The basis is less than the length of the remaining distal segments together. The merus is shorter than the carpus which is longer than the

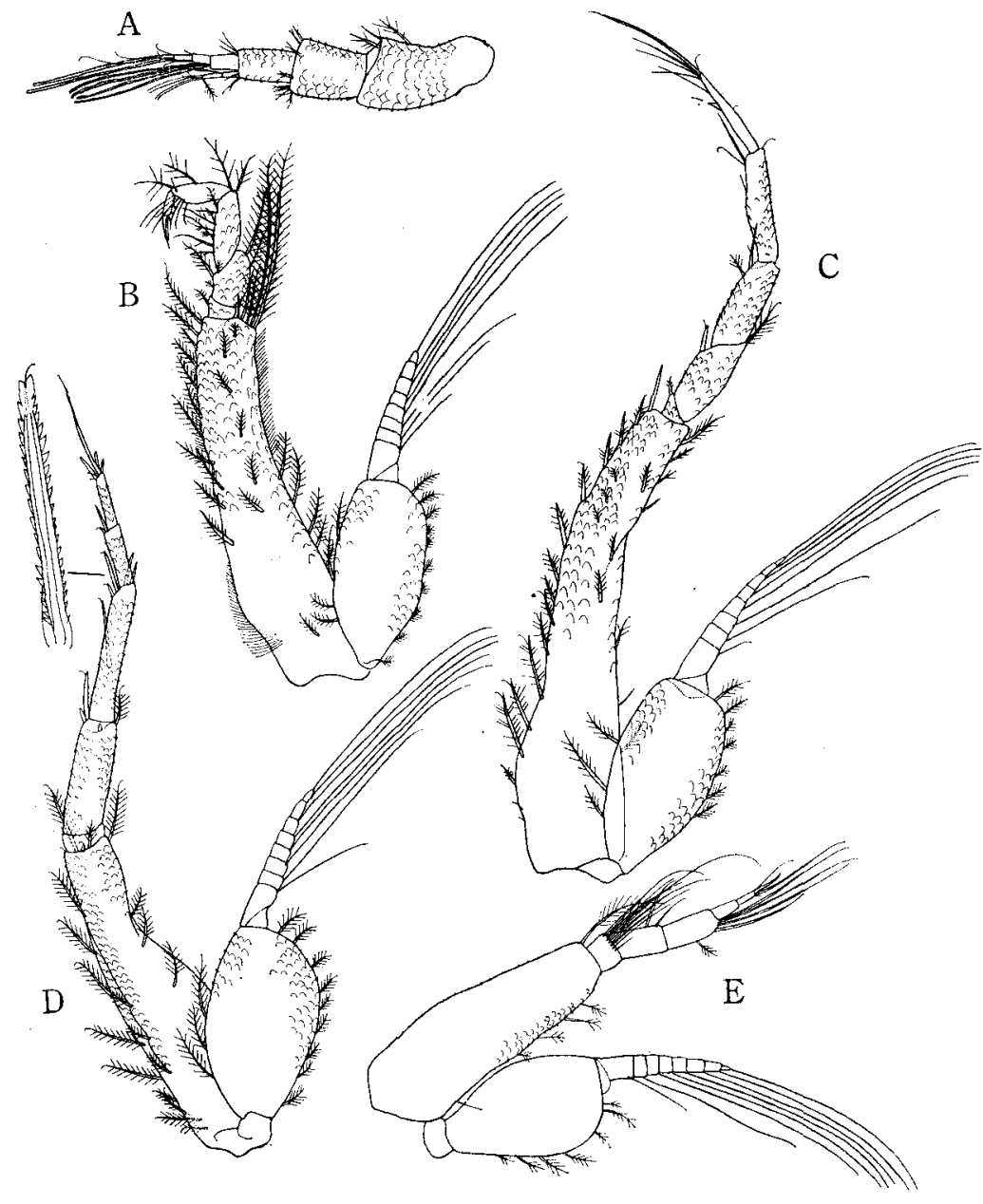

Fig. 4. Lamprops quadriplicata longispina LoMAKINA. Adult male : A : antennule. $\mathrm{B}$ : third maxilliped. $\mathrm{C}$ : first peraeopod. $\mathrm{D}:$ second peraeopod with an enlarged spine on the distal segments. E : third peraeopod.

subequal distal two segments combined. The dactylus is furnished with unequal distal spines, of which the longest one is nearly twice as long as the segment. 
The basis of the third and fourth peraeopods is stout and with a welldeveloped exopod.

The telson is less than one and one-half as long as the last abdominal segment, and bears three pairs of lateral spines and five slender unequal apical spines, of which the outermost two are very long, a little exceeding the length of one-third of the telson; the median spine is of moderate length, about one-half the length of the outermost spines. The peduncle of the uropod is nearly as long as the telson and with spinules on the inner border. The endopod is subequal to the length of the peduncular segment and threesegmented; the proximal segment is one and one-third as long as the subequal distal segments combined and with twelve spines on the inner border and four slender spines on the outer border; the second segment has two spines on the inner border and one on the outer distal border, and the third segment has three distal spines. The exopod is subequal to the length of the endopod and two-segmented; the proximal segment is not beyond the level of the distal end of the first segment of the endopod and much shorter than the distal segment of the exopod; the distal segment bears four long setae on the inner, about six spines on the outer border and two long distal spines, the longest one of which is nearly as long as the segment.

In young female (length, about $2.9 \mathrm{~mm}$ ) and young male (length, about $3.2 \mathrm{~mm}$ ) the carapace is furnished with only four oblique lateral ridges, of which the hindermost one does not reach the lower margin of the carapace (Fig. 2,G). The telson with five apical spines is very like that in the adult condition, but on each of the lateral borders with only one spine. The exopod of the first four peraeopods of the young male is well-developed, but the flagellum of the antenna is not so fully developed as that in the adult condition. In a little more advanced stages of both sexes (more than 2.9 and 3.2 $\mathrm{mm}$ long), the oblique lateral ridges on the carapace and the armatures on the telson successively approach to the adult condition.

The manca larva (length, about $1.8 \mathrm{~mm}$ ) is very like that of the younger specimens mentioned above in having the similar dorso-lateral ridges on the carapace and five apical spines of the telson, but it has only one spine on each of the lateral borders of the telson.

Colouration: Adult ovigerous female is coloured very beautifully when alive, the transparent integument being beset with many chromatophores. The carapace is light brownish with dark brown chromatophores on the frontal lobe and on the dorso-lateral side of the carapace, and the margin of the antennal sinus with two white patches and the lower portion of the carapace with brown chromatophores. The free thoracic segments are clothed with dark and yellow chromatophores on the dorsal surface and with brown patches on the side plates. Brown and yellow chromatophores are also found 
on the posterior dorsal surface of the abdominal segments. The basal part of the telson is coloured brownish and the peduncular segment of the uropod is only apically brownish. The distal part of the first peraeopod is darkly pigmented. The ocelli are reddish. Greenish embryos in the marsupium are seen through the integment.

Material : 5 ㅇ ovigerous, 1 ㅇ with empty marsupium, 4 subadult, $10 \%$ young, $5 \delta$ subadult, 3 o young; night surface tow-net, St. 19, off Shinryu; Aug. 17, 1963. 1 ㅇ subadult, $2 \circ$ juvenile, $1 \delta$ adult, $3 \delta$ young; night surface tow-net, St. 20, off Akkeshi M.B. Station; Aug. 16, 1963. 1 ㅇ young, $1 \&$ juvenile, 1 manca larva ( $\delta$ ?); night surface tow-net, St. 20, off Akkeshi M.B. Station. Aug. 19, 1963. 2 \% subadult; night surface tow-net, St. 21, off Tsukushikoi ; Aug. 16, 1963.

Remarks: The specimens of both sexes taken from Akkeshi Bay closely resemble $L$. multifasciata $Z_{\text {IMMER }}$ (ZIMMER 1937) from the northern part of the Sea of Japan and the Sea of Okhotsk and L. fasciata SARS (SARS 1900) from northern Europe, the White Sea, the Barents Sea and the northern part of the Sea of Japan, but it may be distinguished from the former in having the uropod with the exopod reaching the level of the rear end of the endopod and by that the outer pair of the long apical spines of the telson is a little beyond the length of one-third of the telson and from the latter (o) by the different armature of the telson.

It is closely allied to L. quadriplicata typica SMITH and L. quadriplicata krasheninnikovi Derzhavin, too (Derzhavin 1926 ; Lomakina 1958 b), but differs from them in that the outer pair of the five apical spines of the telson are very long, much longer than the intermediate spines.

The adult specimens are most allied to those of L.quadriplicata longispina LOMAKINA (LOMAKINA 1958 b) in having the telson with an outer pair of long spines and three pairs of lateral spines, but differ from the latter in having the carapace with a short oblique lateral ridge on each of the intermediate spaces between the last three long ridges. In young specimens of both sexes from Akkeshi Bay the carapace have only four oblique lateral ridges as illustrated in Fig. 2, G. The above-mentioned differences from L. quadriplicata longispina seems to be fallen within the range of the geographical or growth variation. Thus the present specimens from Akkeshi Bay are referred to $L$. quadriplicata longispina with some doubt.

Distribution: Zaliv Petra Velinkogo (Peter the Great Bay).

\section{Lamprops sarsi DeRZHAVIN}

(Figs. 5-6)

Lamprops sarsi DeRZHAVIN 1926, p. 177, pl. 5.

L. sarsi ?, ZIMMER 1943, p. 161.

L. sarsi, LOMAKINA 1958 a, p. 138 ; 1958b, p. 88 , fig. 36 . 
Adult female (length, about $3.7 \mathrm{~mm}$ ) with well-developed marsupium, in which twenty embryos are carried.

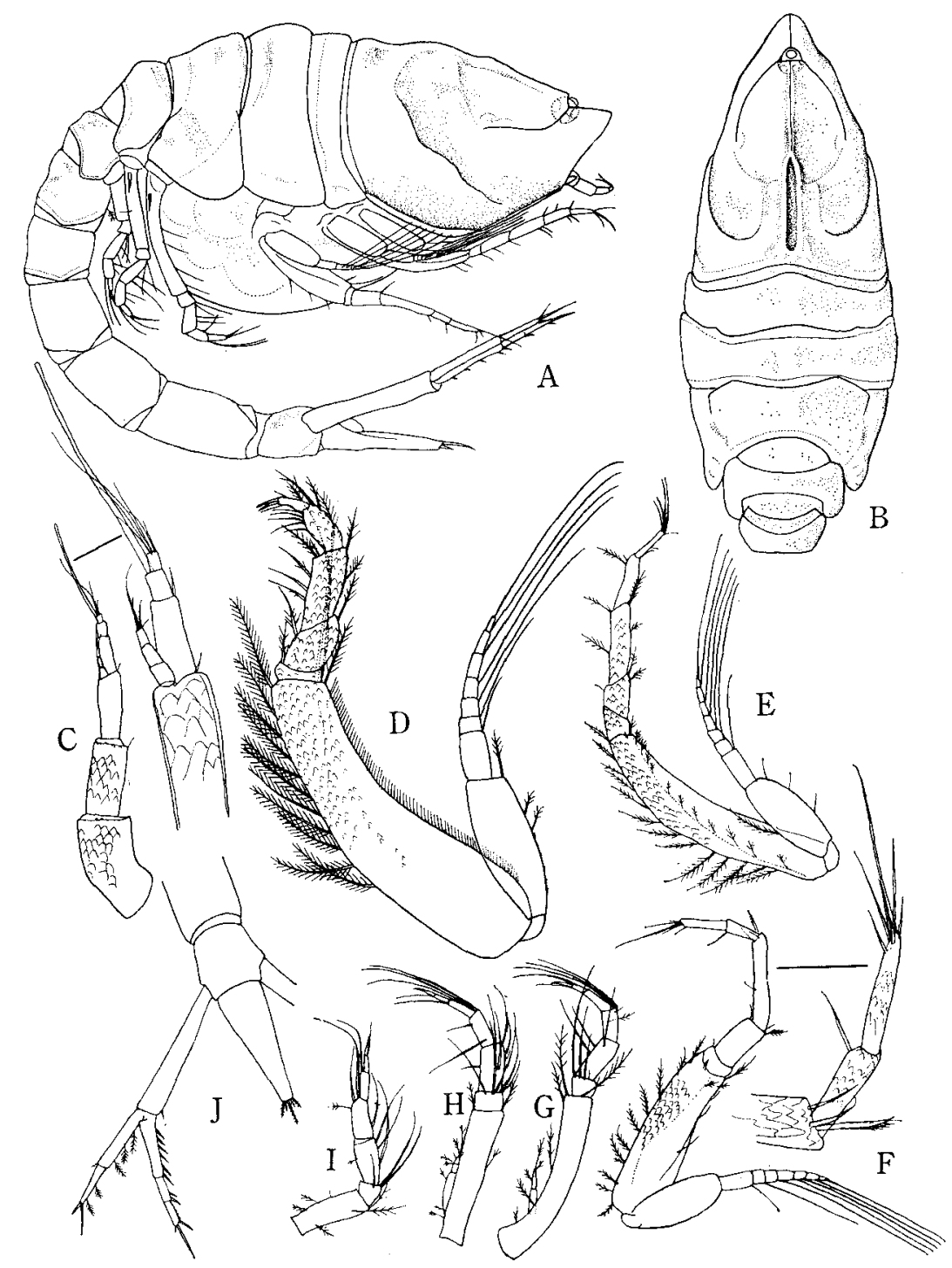

Fig. 5. Lamprops sarsi Derzhavin. Ovigerous female (length, ca. $3.7 \mathrm{~mm}$ ) : A : lateral view. B : anterior portion of body, from above. C : antennule. $\mathrm{D}$ : third maxilliped. E-I : first to fifth peraeopods. $\mathrm{J}:$ telson and uropod with last two abdominal segments.

The carapace is furnished with two oblique lateral ridges; one is faintly marked on the dorso-lateral portion just behind the frontal lobe; the another 
one is fairly well-marked and extends obliquely downwards from the dorsomedian portion to the lower margin of the carapace. The dorso-median carina is rather well-marked; the anterior half of the carina with a longitudinal median line, and the posterior half becomes doubled by a longitudinal median shallow depression. The length of the carapace is a little more than onefourth of the total length of the animal and nearly one and one-third the width, which is a little more than the depth. The ocular lobe is round. The antennal notch is obsolete.

The combined length of all the free thoracic segments is a little more than the length of the carapace. The first three segments are wider than the carapace. The second and third segments are rather large and the sides are expanded laterally. The fifth segment is very small.

The abdomen is much less than one-half of the total length of the animal. The first two segments are of equal size and the following segments are successively increased in length. The fifth segment is about one and onesixth the length of the fourth one. The sixth segment is small and about one-half as long as the fifth.

The first segment of the peduncle of the antennule is nearly three-fourths as long as the subequal two distal segments combined. The main flagellum is large, a little shorter than the third segment of the peduncle and threesegmented; the first segment is very long; the distal two segments are small and the third one with a long aesthetascs. The accessory flagellum is threefourths the length of the first segment of the main flagellum and with three segments; each is nearly subequal in length.

The basis of the third maxilliped is slightly shorter than one and twothirds as long as the remaining distal segments together. The ischium is short. The carpus is one and one-half the length of the merus. The dactylus is nearly one-half the length of the propodus which is slightly more than one-half the length of the carpus.

The basis of the first peraeopod is equal to one and one-sixth as long as the remaining distal segments together and bears plumose setae on the inner border, of which the distal two are spiniform. The ischium is a little less than the length of the merus. The carpus is much more than the combined

- length of the ischium and merus. The propodus is three-fourths as long as the carpus. The dactylus is nearly two-thirds the length of the propodus and provided with four long distal spines.

The second peraeopod is about six-sevenths of the length of the first peraeopod. The basis is nearly three-fourths as long as the remaining distal segments together. The carpus is rather long, nearly twice as long as the merus and much more than the combined length of the distal two segments. The dactylus is longer than the propodus and provided with unequal six 
distal spines like setae, the longest one of which is much beyond the length of the dactylus.

The third peraeopod is a little longer than the fourth one. The last three pairs of the peraeopods are shown in Fig. 5, F-I.

The telson is slightly less than twice as long as the last abdominal segment and furnished with five plumose spines at the distal end; the median one is the longest and outermost two are moderate in length. The peduncle of the uropod is slightly longer than the telson and with a spine on the distal inner margin. The endopod is a little shorter than the peduncular segment and three-segmented; the proximal segment is nearly as long as the distal subequal two segments combined and with six spines on the innner border; the second segment with two spines on the distal part of the inner border; the third segment with three serrations and a spine on the inner border and with a long distal spine much exceeding the length of the segment. The exopod is nearly as long as the endopod and bears two segments; the proximal segment slightly exceeds the length of the first segment of the endopod in the natural position and provided with three or four plumose hairs on the inner border; the distal segment is shorter than the proximal one, with two plumose setae on the inner border and two unequal distal spines.

Adult male (length, about $2.7 \mathrm{~mm}$ ): The integument is thin and semitransparent. The carapace is furnished with two oblique lateral ridges; one ridge is just behind the frontal lobe and the another one is situated on the lateral portion. The dorso-median carina is very faintly marked on the anterior half and there is a longitudinal shallow depression on the posterior half. The length of the carapace is nearly two-sevenths of the total length of the animal and a little more than one and one-half the width, which is slightly less than the depth. The antennal notch is obsolete.

The combined length of all the free thoracic segments is much less than the length of the carapace. The first to fifth segments are successively decreased in width as well as in depth; the side plates are rather prominent.

The abdomen is slightly less than one-half of the total length of the animal. The first two segments are nearly of equal length. The third and fourth segments are subequal and a little longer than the first or the second one. The fifth is nearly one and one-fourth as long as the fourth. The sixth is a little shorter than the fifth.

The first segment of the peduncle of the antennule is a little shorter than the distal two segments combined. The second segment is longer than the third one. The main flagellum is three-segmented and with a small protuberance like a segment and two long aesthetascs at the distal end of the third segment.

The flagellum of the antenna is well-developed and reaches the level of 


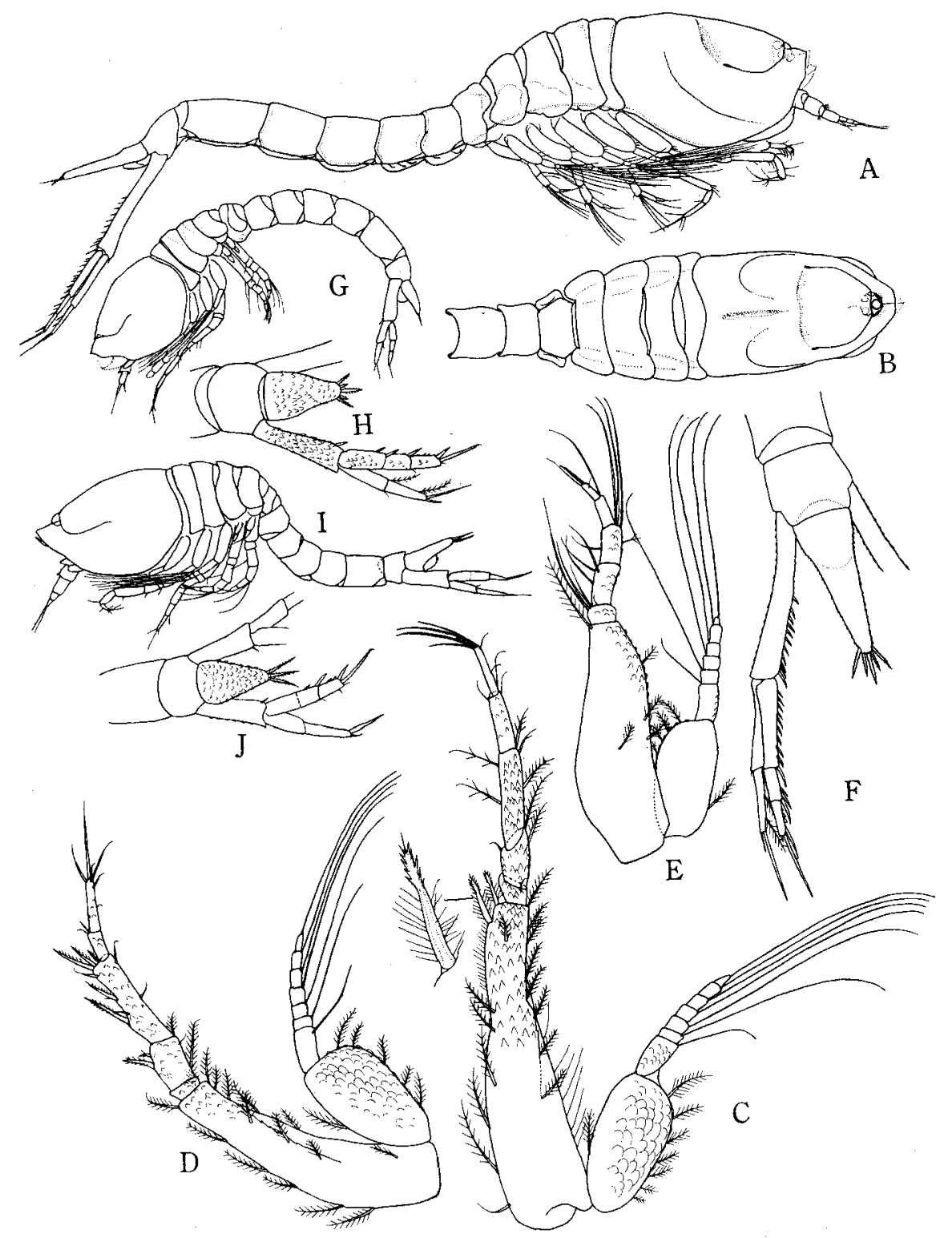

Fig. 6. Lamprops sarsi DERzHAVIN. Adult male (length, ca. $2.7 \mathrm{~mm}$ ) : A : lateral view. B : anterior portion of body, from above. C-E : first to third peraeopods. $\mathrm{F}$ : telson and uropod with last abdominal segment. Large manca larva (length, ca. $2.3 \mathrm{~mm}$ ) : $\mathrm{G}$ : lateral view. $\mathrm{H}$ : telson and uropod with last abdominal segment. Small manca larva (length, ca. $1.0 \mathrm{~mm}$ ) : I : lateral view. J : telson and uropod with last abdominal segment. 
the end of fifth abdominal segment.

The basis of the first peraeopod bears two large plumose spines on the inner distal angle. The ischium is one-half the length of the merus. The dactylus is a little less than the length of the propodus which is less than three-fourths as long as the carpus.

The basis of the second peraeopod is a little more than the length of the remaining distal segments together. The carpus is more than twice as long as the merus and provided with two plumose spines on the inner border and three such unequal spines on the inner distal end. The dactylus bears five spines like setae on the distal end, one of which is much beyond the length of the dactylus.

The basis of the third (Fig. 6,E) and fourth peraeopods bears a welldeveloped exopod.

The telson is a little longer than twice of the last abdominal segment and provided with five apical plumose spines; the median spine is long; the outermost two are moderate and the other two are rather short. The peduncle of the uropod is more than the length of the telson and bears eleven spines on the inner border. The endopod is a little less than the length of the peduncular segment and three-segmented; the first segment is much longer than the subequal distal two segments together and with ten spines on the inner border; the second segment has three spines on the distal inner margin; the third segment is furnished with three small teeth and a spine on the inner border and with a long distal spine about twice as long as the segment. The exopod is about subequal to the length of the endopod and two-segmented; the proximal segment is nearly as long as the first segment of the endopod and with three plumose hairs on the inner border.

Manca larva: Three manca larvae were collected and observed. One of them is very small, about $1.0 \mathrm{~mm}$ long (Fig. 6, I-J). The exopod of the first two peraeopods bears plumose hairs on the distal segments. The basis of the third and fourth peraeopods is provided with a rudimentary exopod. The last free thoracic segment has no peraeopod. The telson is only provided with three rather long distal spines. The peduncular segment of the uropod has a small spine on the distal inner border. The endopod is three-segmented (?) (the proximal two segments are indistinct). In another two specimens of the manca larvae the body length is about $2.3 \mathrm{~mm}$ (Fig. 6, G-H). The telson bears five distal spines which are very like those of the specimen in much advanced stages. The distal portion of the uropod has a small lateral spine. The endopod is three-segmented. The distal segment of the exopod has two plumose hairs on the inner border.

In several specimens of both sexes (adult and subadult) the lateral oblique ridges on the carapace are indistinct. 
Colouration: In life the integument of the subadult female is translucent and furnished with many beautiful chromatophores, and the brownish yellow contents of the digestive tube are visible through it. The carapace is beset with many chromatophores on the dark yellowish background ; there are found two black patches, one extends below the ocular lobe to the obsolete anterolateral sinus and the other is on the middle part of the lower margin of the carapace. The dark brownish chromatophores are distributed from just behind the frontal lobe to the most part of the postero-lateral portion of the carapace, which is marked with whitish patches. The brown-coloured ocular lobe is beset with reddish ocelli.

The free thoracic segments are also dark yellowish in general as well as the carapace, the dorso-median part and the lateral side of which are dark brownish.

The abdomen is colourless, but the posterior half of the fifth segment is coloured dark brown. The telson base is also dark brown on the dorsal side.

The antennule, third maxilliped and the proximal segment of the first three peraeopods are coloured brownish, whereas the remaining peraeopods and uropod are colourless.

Material : 2 \% with marsupium, 1 manca larva ( $\delta$ ?); St. 6, $0.3 \mathrm{~m}$ below low tide level, fine sandy bottom; Aug. 19, 1963. 2ઈ, 1 manca larva ( $\delta$ ?); St. 10, depth $14 \mathrm{~m}$, sandy mud bottom; Aug. 17, 1963. 1 \% ovigerous, 1 \% with empty marsupium, $12 q$ with developing marsupium, 1 ㅇ subadult, $19 \delta$; night surface tow-net, St. 19, off Shinryu; Aug. 17, 1963.1 우 ovigerous, 1 ㅇ young, $1 \delta$ adult; night surface tow-net, St. 20, off Akkeshi M.B. Station ; Aug. 16, 1963. Iิ adult, 1 t young, 1 manca larva ( $\delta$ ?); night surface tow-net, St. 21, off Tsukushikoi ; Aug. 16, 1963. 1 s young; night surface tow-net, St. 21, off Tsukushikoi ; Aug. 19, 1963.

Remarks: The adult ovigerous female in the present collection conforms well to Derzhavin's (1962) original description and figure of the adult female with marsupium from Kamtschatka, from which the former differs in the following points : 1) body is much smaller than Derzhavin's specimen ( $4.3 \mathrm{~mm}$ ), 2) the dactylus of the second peraeopod with long spines, of which the longest one exceeds the length of the dactylus, 3) the combined length of all the free thoracic segments is a little more than the carapace length (scarcely shorter than the carapace in Derzhavin's specimen), and 4) the telson is slightly less than twice as long as the last abdominal segment (nearly 2.5 times the last abdominal segment in Derzhavin's specimen).

The adult male from Akkeshi Bay is much smaller than Derzhavin's specimens and the young male $(4.5 \mathrm{~mm}$ long) described from Alaska as $L$. sp. (sarsi Derzhavin) by Zimmer (1943). The former differs from the latter two in the following characters: 1) the specimen is smaller, 2) the abdomen, inclusive of the telson, is much longer than the cephalothoracic portion (as long as the cephalothoracic portion in Derzhavin's female and ZimMER's male), 3) the peduncular segment of uropod a little exceeds the level of the tip of telson and with eleven spines on the inner border (five spines in ZIMMER's young 
male), and 4) the telson is a little more than twice as long as the last abdominal segment (one and a half times in Zimmer's young male and twice in DerzhAvin's specimen).

It seems to me that such differences are attributable to the geographic variation. And thus the present specimens are referred to L. sarsi DeRzhavin on the basis of the existence of two oblique lateral ridges on the carapace (if present), the similarities in the armature 'of telson and uropod, and the resemblance of the shape of telson and uropod themselves.

Distribution: Alaska (Kodiak Island), Bering Sea (Olyutorsky bay), East coast of Kamchatka (Avachinskaya Guba), Northern part of Sea of Okhotsk (Tauiskaya Guba), Tartary Strait (Mys Syurkum).

\section{Family Diastylidae}

\section{Diastylis alaskensis CALMAN}

(Figs. 7-9)

Diastylis alaskensis CALMAN 1912, p. 641, figs. 51-57.

D. alaskensis, StebBing 1913, p. 93.

Mesostylis alaskensis Derzhavin 1926, p. 175, Taf. 3, figs. 1-3.

Diastylis alaskensis, ZIMMER 1937, p. 43.

D. alaskensis, Lomakina $1955 \mathrm{a}$, p. $141 ; 1955 \mathrm{~b}$, p. 125 , Taf. 27 , fig. $1 ; 1958 \mathrm{a}$, p. $209 ; 1958 \mathrm{~b}$, p. 123, figs. 6-7.

Adult male (length, about $7.7 \mathrm{~mm}$ ): The carapace is provided with six transverse ridges; one encircles the base of the pseudorostrum and the another two are acrossed on the frontal lobe and extend to the lower part of the antero-lateral surface; the following three ridges are also acrossed on the dorsal surface and then obliquely transversed on the lateral surface. The dorso-median carina is very faintly marked on the frontal lobe. On the posterior portion there is a shallow median longitudinal depressed area which interrupts the hindermost transverse ridge. On each lateral surface there is a horizontal ridge which runs forwards from the hind marginal edge of the carapace to the last two transverse ridges a little way above the lower margin of the carapace. The length of the carapace is about two-sevenths of the total length of the animal. It is widest across the one-fourth posterior portion about three-fourths the length of the carapace and one and one-half times the depth. The pseudorostral lobes meet in front of the ocular lobe for a distance about equal to one-seventh of the carapace length. The antennal notch is obsolete and very shallowly sinuated. The antero-lateral margin is broadly rounded and with small serrations and several long hairs.

The combined length of all the free thoracic segments is nearly fivesixths of the length of the carapace. There is a longitudinal dorso-median 
strong ridge on the fourth segment. The side plate of the second to fourth segments is expanded laterally. The pleural plate of the third segment is possibly overlap that of the second one. The postero-lateral process of the last segment is very prominent and terminates with a small tooth. The sternites of the second to fifth thoracic segments have each a median ventral spine; the third and fourth thoracic sternites with an anchor-like spine (Fig. $7, \mathrm{C})$.

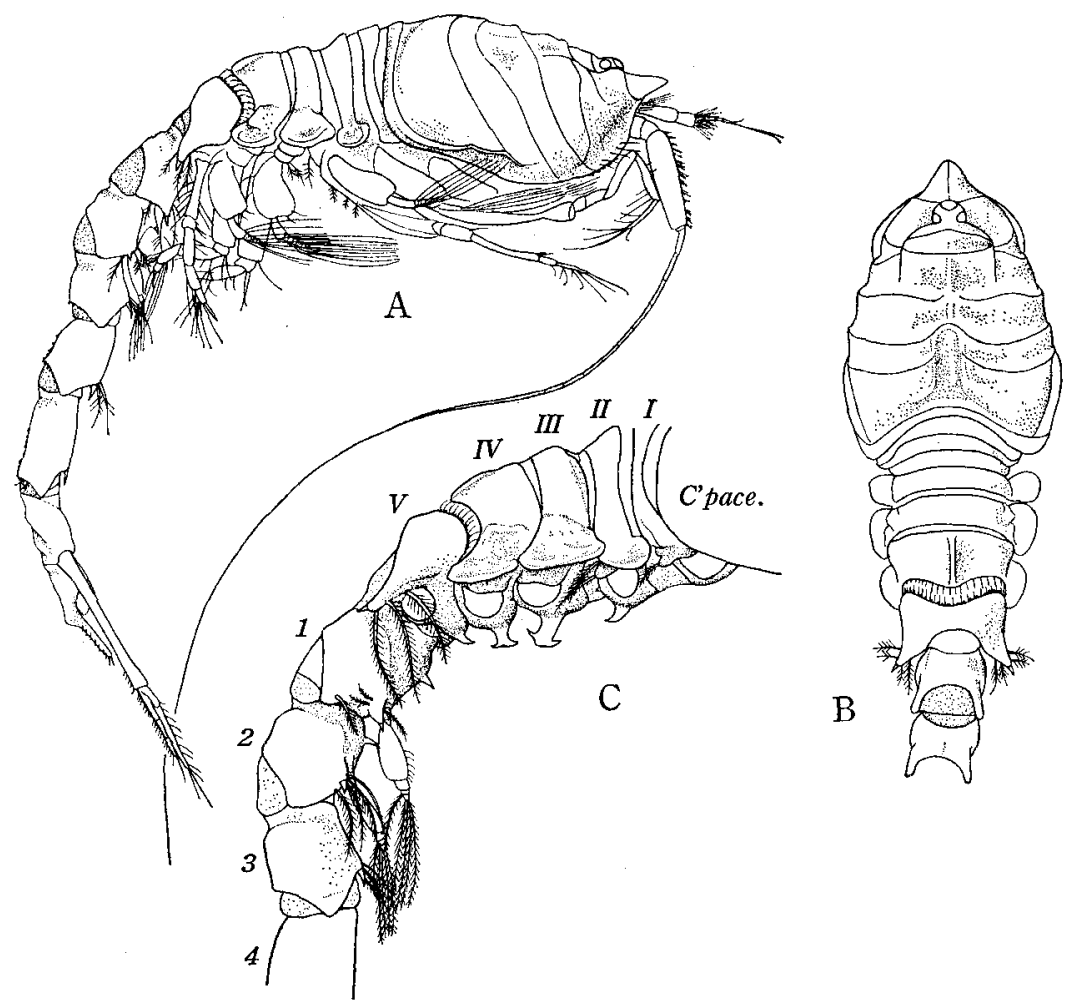

Fig. 7. Diastylis alaskensis CALMAN. Adult male (length, ca. $7.7 \mathrm{~mm}$ ): A : lateral view. B : anterior portion of body, from above. $\mathrm{C}$ : ventral spines on the thoracic and abdominal sternites, from side.

The abdomen is rather slender and nearly one-half of the total length of the animal. The dorso-median line of the fourth to sixth segments is a little carinate. The first two segments have each a small ventral spine. In addition there is a small spine on the postero-lateral lower angle of the first five segments. The fifth segment is long, about one and one-half the length of the sixth.

The first segment of the peduncle of the antennule is nearly one and two-thirds as long as the second segment which is a little less than the third 
one; the third segment bears many long hairs on the distal margin. The main flagellum is about one and three-fourths as long as the third peduncular segment, four-segmented and with two long subequal aesthetascs about equal to the length of the main flagellum; the second segment of the main lash

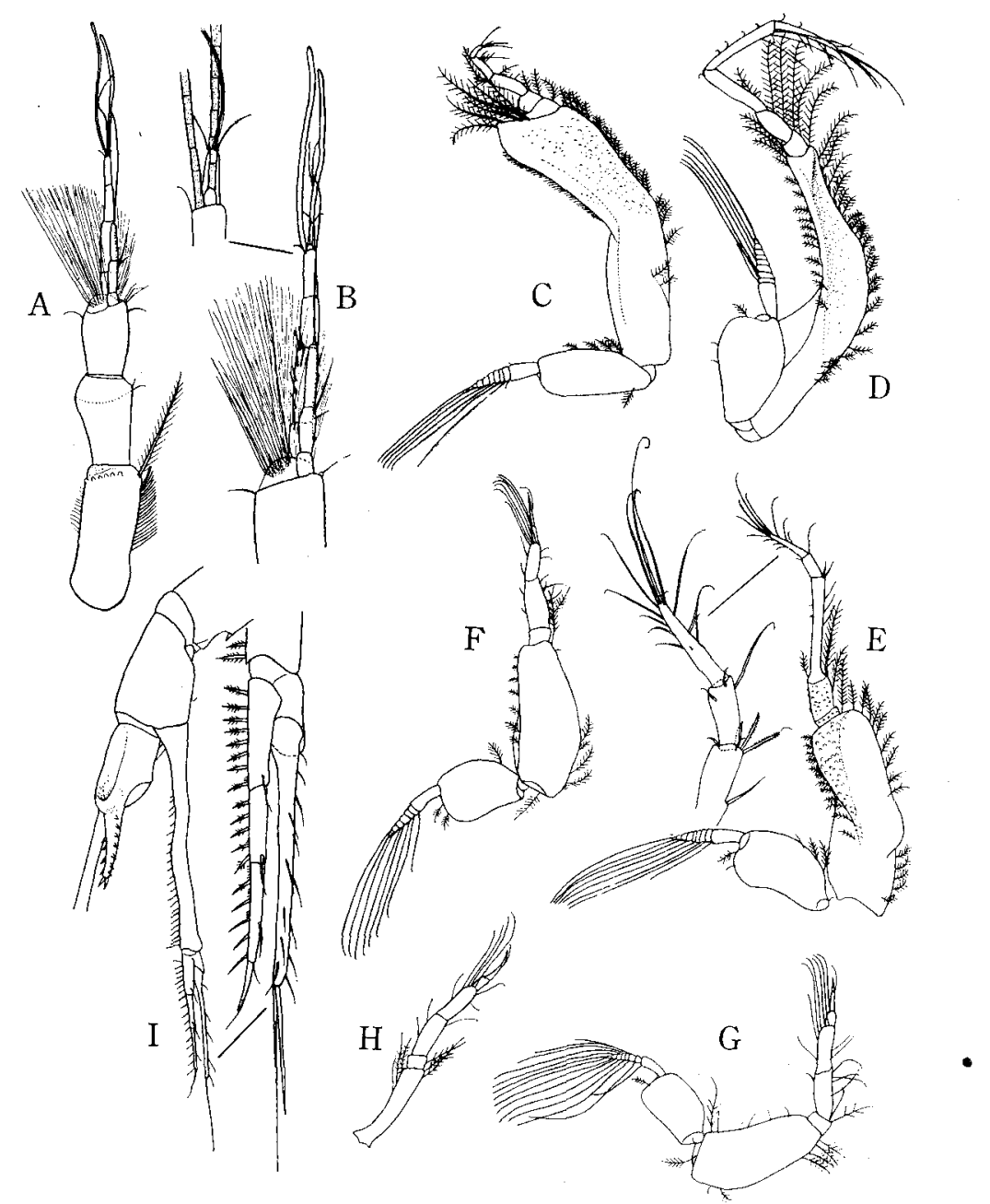

Fig. 8. Diastylis alaskensis CALMAN. Adult male : A : antennule. B : distal portion of antennule. $\mathrm{C}$ : third maxilliped. $\mathrm{D}-\mathrm{H}$ : first to fifth peraeopods. I : telson and uropod with last two abdominal segments.

is long; the fourth segment is furnished with a small tubercle like a segment at the distal end. The accessory flagellum is slightly longer than one-half of the main flagellum and three-segmented.

The basis of the third maxilliped is a little longer than the remaining 
distal segments together and with short plumose hairs and small teeth on the inner border; the external angle is broadly expanded and with plumose hairs. The ischium is broad and nearly as long as the merus. The carpus is rather slender and about equal to the combined length of the merus and ischium. The dactylus is one-half of the length of the propodus which is a little less than the length of the carpus.

The basis of the first peraeopod is longer than the remaining distal segments together and furnished with small serrations on the distal part of the inner border and with plumose hairs on both lateral borders. The carpus is one-half the legnth of the merus. The carpus is provided with three long setae on the distal inner angle and the length is a little shorter than the ischium and merus together and a little shorter than the propodus. The dactylus is a little shorter than the propodus and provided with long distal setae, one of which exceeds the length of the segment.

The second peraeopod is about two-thirds as long as the first one. The basis is robust and furnished with plumose hairs and nearly equal to the length of the remaining distal segments together. The ischium is very short. The carpus is slender and about two and two-thirds times as long as the distal two segments combined. The dactylus is nearly one and one-third times the length of the propodus and bears long distal setae, one of which much exceeds the length of the segment.

The third peraeopod is a little shorter than three-fourths of the length of the second and a little longer than the fourth one. The basis of the third peraeopod is less than the combined length of all the remaining distal segments. The basis of the fourth peraeopod is nearly as long as the remaining distal segments together. The fifth peraeopod is much shorter than the fourth one.

The telson is one-third the length of the last abdominal segment; its pre-anal portion is a little longer than one-half of the telson and on the dorsal surface there is a depressed area margined with a low ridge; the narrow post-anal portion is projected backwards and with seven or six short spines on each lateral side and two spines at the distal end. The peduncle of the uropod is slender, about one and one-half as long as the telson and furnished with about twenty spines on the inner border. The endopod is one-half as long as the peduncular segment and three-segmented; each with eight or five lateral spines on the inner and a seta on the outer border and the third one with a terminal spine. The exopod is nearly as long as the endopod, setose and provided with unequal spines.

Adult female (length, about $9.3 \mathrm{~mm}$ ) with well-developed marsupium, in which about 150 embryos, about $0.3 \mathrm{~mm}$ in diameter are carried. The colour of body in life is dirty white in general; the carapace is yellowish. 
The surface of the carapace is covered with minute spiniform tubercles and provided with seven ridges almost encircling the carapace. Each of the ridges is fringed with fine tubercles like spinules; the first one of the ridges
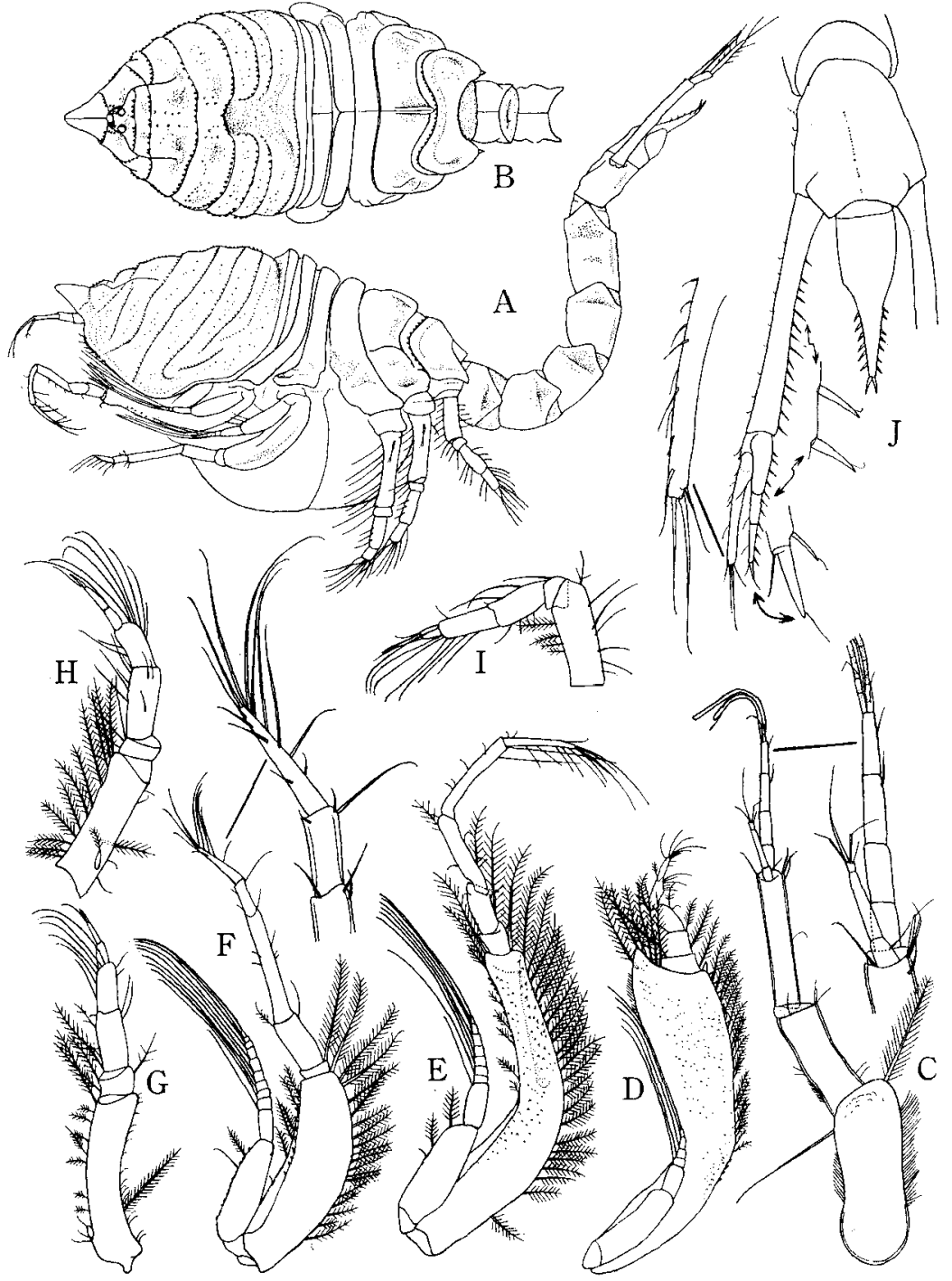

Fig. 9. Diastylis alaskensis CALMAN. Ovigerous female (length, ca. $9.3 \mathrm{~mm}$ ): A : lateral view. B : anterior portion of body, from above. $\mathrm{C}$ : antennule. $\mathrm{D}:$ third maxilliped. E-I : first to fifth peraeopods. $\mathrm{J}:$ telson and uropod with last abdominal segment.

encircles the base of the pseudorostrum; the following two run downwards from the frontal lobe to the antero-lateral surface; the third and fourth ridges 
just behind the frontal lobe almost encircle the carapace and the hindmost two obliquely run from the antero-lateral portion to the lower margin of the carapace. On the postero-dorsal surface of the carapace there is a shallow depressed area which interrupts the hindmost two transverse ridges. The carapace is almost fusiform as seen from above; it is widest across the posterior portion, about six-sevenths as long as the animal; its depth is about four-fifths of its wideth. The antennal notch is shallowly sinuated and the antero-lateral corner is rounded and serrated on the lower margin with several hairs. The round ocular lobe is beset with three ocelli. The pseudorostal lobes meet in front of the ocular lobe for a distance about equal to one-seventh of the length of the carapace.

The combined length of all the free thoracic segments is a little less than the length of the carapace. The dorso-median carina is less distinct on the first four segments and strongly marked on the fourth segment. The pleural plates are fairly distinct. The postero-lateral process of the last segment is rather blunt.

The abdomen is less than one-half of the total length of the animal. The fifth segment is longer than the others. The sixth segment is two-thirds the length of the fifth one.

The first segment of the peduncle of the antennule is a little longer than one and one-half of the second segment which is about three-fourths the length of the third one. The main flagellum is slender and a little shorter than the third peduncular segment and three-segmented; the distal segment of the main lash with a small protuberance like a segment and with rather long two aesthetascs. The accessory flagellum is long, nearly reaching the level of one-half the length of the main flagellum; the second segment of the accessory lash is very long.

The basis of the third maxilliped is nearly two and two-thirds as long as the remaining distal segments together. The ischium is broad and slightly shorter than the merus. The carpus is longer than the merus. The dactylus is slightly shorter than the propodus which is a little less than the length of the carpus.

The basis of the first peraeopod is covered with sparse minute tubercles like spines and furnished with plumose hairs on the inner border and also at the distal end; its length is shorter than the remaining distal segments together. The ischium is slightly less than two-thirds the length of the merus. The carpus is a little longer than the ischium and merus together and nearly as long as the propodus. The propodus bears two long setae on the inner distal margin. The dactylus is subequal to three-fourths as long as the propodus and provided with two setae longer than the dactylus proper at the distal end. 
The second peraeopod is less than three-fourths of the length of th first peraeopod. The basis is furnished with plumose hairs on both lateral borders and four-fifths the length of the remaining distal segments together. The ischium is very short. The carpus is slender, almost twice as long as the merus, and much longer than the distal two segments combined. The dactylus is one and one-half as long as the propodus and provided with long distal setae, the longest one of which much exceeds the length of the segment.

The third peraeopod is about three-fourths as long as the second one and a little longer than the fourth one. The basis of the third peraeopod with a rudimentary exopod is slightly less than the combined length of the remaining distal segments. The basis of the fourth one with a rudimentary exopod is much shorter than the remaining distal segments together. The fifth peraeopod is much shorter than the fourth peraeopod.

The telson is a little longer than the last abdominal segment; the preanal portion is about one-half of the total length of the telson. The post-anal portion is furnished with six or seven short spines on each lateral border and with two distal spines. The peduncle of the uropod is one and one-half times as long as the telson and bears fourteen spines on the inner border. The endopod is a little more than one-half the length of the peduncular segment and three-segmented; the first segment is slightly longer than the combined length of the distal subequal two segments and each bears three or five spines on the inner border; the third one with an apical spine. The exopod is nearly equal to the length of the endopod and bears setae on the outer border and two long setae at the distal end.

Adult female with developing marsupium (length, about $10.1 \mathrm{~mm}$ ): The general features are very like those of the adult ovigerous female. The carapace is covered with minute spiniform granules. The telson has four (on the right side) or five (on the left side) lateral spines and two short apical spines.

Young female (length, about $5.6 \mathrm{~mm}$ ): The general appearance of the carapace is somewhat aberrant at a glance in having much more conspicuous transverse folds or ridges on the carapace. Each of the ridges almost encircles the carapace like those in the adult female. The surface of the carapace is covered with armatures like minute tuberculate granules and partly clothed with minute spiniform granules. The telson is one and onehalf as long as the last abdominal segment and provided with two lateral spines on each side and two short apical spines. The peduncle of the uropod is slightly shorter than the telson and with five spines on the inner border. The endopod is three-fourths as long as the peduncular segment and threesegmented; the second segment is very short. 
Young male (length, nearly $5.6 \mathrm{~mm}$ ): The general appearence of the body is very like that of the young female.

In juvenile specimens of both sexes and in manca larva (length, about 1.8 and $1.4 \mathrm{~mm}$ ), the general appearence of the body is very like that in the advanced stages described above, with the exception of the carapace without spiniform granules and the different proportional length of the parts of the body. The telson has only two relatively shorter apical spines in the small manca larva, whereas in the larger form the telson has two apical spines and a pair of short lateral spines.

Material : 1 ㅇ subadult, $2 \%$ juvenile, 1 manca larva; St. 8 , depth $8 \mathrm{~m}$, sandy bottom; Aug. 16, 1963. 2 o juvenile, 1 manca larva; St. 10, depth $14 \mathrm{~m}$, sandy mud bottom; Aug. 17, 1963. 3 o ovigerous, 1 \% young; St. 14, depth $13 \mathrm{~m}$, sandy mud bottom; Aug. 16, 1963. 1 \% juvenile, $1 \delta$ adult, $1 \delta$ juvenile, 3 manca larvae; night surface tow-net, St. 20, off Akkeshi M.B. Station ; Aug. 16, 1963. 2 ㅇ juvenile, $2 \delta$ juvenile, 6 manca larvae; night surface tow-net, St. 21, off Tsukushikoi ; Aug. 18, 1963. 1 manca larva; night surface tow-net, off Tsukushikoi ; Aug. 19, 1963.

Remarks: The adult specimens from Akkeshi Bay are rather smaller and differ from those described by Calman (1912), Derzhavin (1926) and Lomakina (1958 b) in the following points: 1) In the adult male the distinct sixth transverse ridge is present on the carapace and the antero-lateral corners of the carapace are much more rounded and slightly more expanded than in Calman's original figure, the sternite of the second to fifth thoracic segments is furnished with a conspicuous median ventral spine and also the first two abdominal segments with a ventral spine, and there is a lateral spine on each postero-ventral angle of the first to fifth abdominal segments. 2) In the adult female, the carapace is much more stouter and broader than in Calman's and Lomakina's figures and the antero-lateral corners of the carapace are a little expanded, the peduncle of the uropod is much shorter than in Calman's specimen.

The young animals and manca larvae taken from Akkeshi Bay somewhat resemble those from the adult specimens illustrated by Calman, Derzhavin and Lomakina and also very like those of D. lazarevi.

This species resembles very closely $D$. lazarevi Lomakina, from which it is distinguishable by the following characters : both the two transverse ridses just behind the frontal lobe encircle the carapace almost annularly and the telson has two relatively shorter apical spines.

The specimens from Akkeshi Bay may probably be identified with $D$. alaskensis in spite of the existence of some differences of the growth or geographical variation.

Distribution: Chukotsk Sea, Bering Sea, Sea of Okhotsk, northern part of Sea of Japan and Pacific coast of the North America. 


\section{Diastylis lazarevi LomaKinA}

(Figs. 10-11)

Diastylis lazarevi Lomakina 1955a, p. 144, figs. 39-41; 1958b, p. 125, fig. 68.

Young female (length, about $5.4 \mathrm{~mm}$ ): The surface of the carapace is clothed with minute reticulated patterns and furnished with seven transverse ridges which are fringed with minute granules like spinules. The fourth ridge just behind the frontal lobe encircles the dorsal surface of the carapace, whereas the next two ridges are interrupted on the dorsal surface by a shallow depression and each is turned forwards and conected with one another; the fifth ridge connects with a faint ridge which traverses the dorsal depression. The length of the carapace is nearly one-third of the total length of the animal, and one and one-fifth the width, which is much more than the depth. It is widest across the one-third posterior region and much raised postero-dorsally. The antennal notch is shallowly sinuated and the anterolateral or lower margin of the carapace is rounded and margined with small serrations. The pseudorostral lobes meet in front of the ocular lobe for a distance about one-sixth as long as the carapace and project somewhat upwards. The ocular lobe is semicircular in shape and beset with three ocelli.

The combined length of all the free thoracic segments is a little less than three-fourths the length of the carapace. The first two segments are short. The dorso-median portion of the fourth segment is a little raised. The lateral side of the second to fifth segments is much prominent. The postero-lateral corner of the fifth segment is projected downwards.

The abdomen is much less than one-half the length of the carapace and furnished with fine reticulated tubercles like those on the surface of the carapace. The first four segments are nearly of equal size and the fifth is a little longer than the fourth or the sixth segment.

The first segment of the peduncle of the antennule is about three-fourths the length of the distal two segments combined; the second segment is nearly equal to the length of the third one. The main flagellum is a little longer than the third peduncular segment, three-segmented, and bears two long aesthetascs and a small protuberance like a segment. The accessory flagellum is rather large with three segments; the second segment is long and the distal one is very small.

The basis of the third maxilliped is large, expanded distally, longer than twice of the remaining distal segments together, and with a stout tooth on the inner angle and teeth and plumose hairs on the inner border; the external angle is developed into a broad protuberance which reaches the level of the distal end of the ischium. The merus is one-half the length of the carpus and with a long plumose hair on the middle of the external border. The 


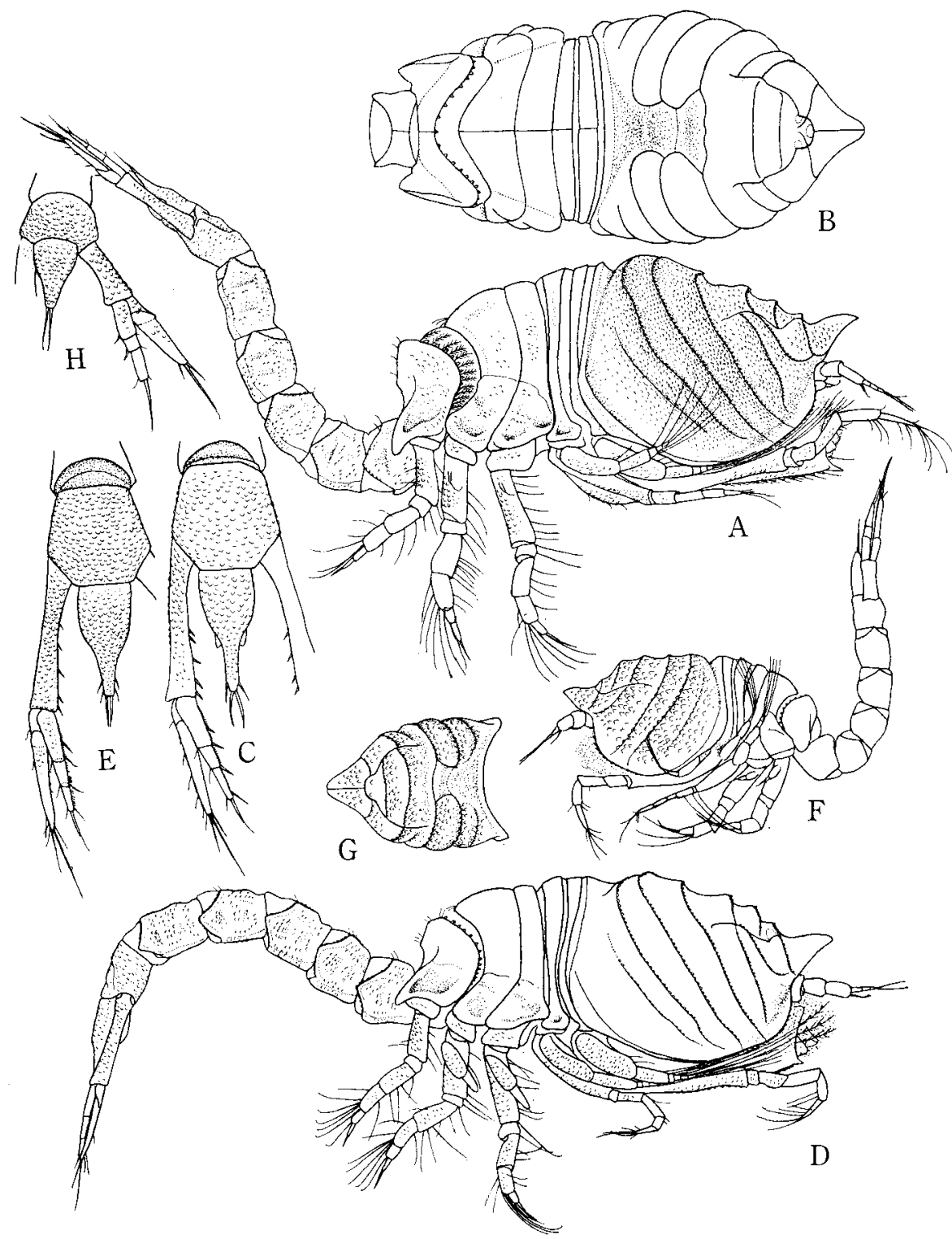

Fig. 10. Diastylis lazarevi Lomakina. Young female (length, ca. $5.4 \mathrm{~mm}$ ) : A : lateral view. B : anterior portion of body, from above. $C:$ telson and uropod with last abdominal segment. Young male (length, ca. $5.0 \mathrm{~mm}$ ) : D : lateral view. $\mathrm{E}:$ telson and uropod with last abdominal segment. Manca larva (length, ca. $1.9 \mathrm{~mm}$ ) : F : lateral view. $\mathrm{G}$ : carapace, from above. $\mathrm{H}$ : telson and uropod with last abdominal segment. (B and D : sculptures on surface of cephalothoracic portion are omitted). 
carpus with a broad white-coloured band is one and one-half the length of the propodus and has a plumose hair on the external angle. The dactylus is a little shorter than the propodus and bears seven distal setae or spines.

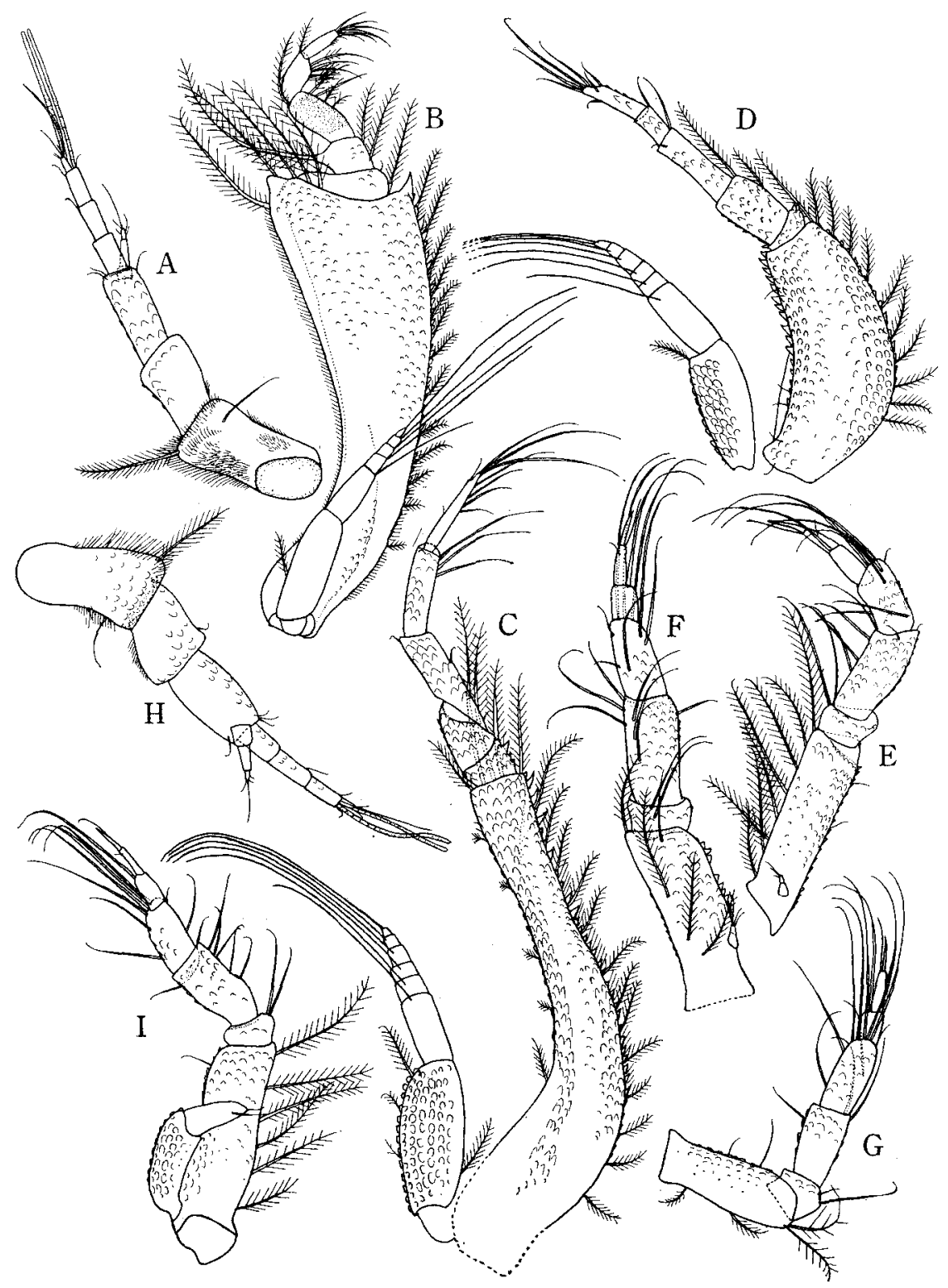

Fig. 11. Diastylis lazarevi Lomakina. Young female : A : antennule. B : third maxilliped. C-G : first to fifth peraeopods. Young male : $\mathbf{H}:$ antennule. I : third peraeopod. 
The basis of the first peraeopod is rather slender, a little more than one and one-half the length of the remaining distal segments together (as measured along the middle line of the basis) and with teeth and plumose hairs on the inner border. The ischium is one-half the length of the merus and provided with teeth on the inner border. The carpus is nearly one and twothirds as long as the merus and one and one-third the length of the propodus. The dactylus is subequal to the propodus in length and bears three long apical setae like spines.

The second peraeopod is three-fifths the length of the first peraeopod. The basis of the second peraeopod is robust, slightly longer than the remaining distal segments together and beset with small tubercles on the ventral surface. The ischium is short. The carapace is a little longer than the merus and shorter than the propodus and dactylus combined. The dactylus is a little less than twice as long as the propodus and bears four unequal apical setae, of which the longest one exceeds the length of the distal two segments combined.

The third peraeopod is six-sevenths of the lenth of the second peraeopod; the basis is nearly four-fifths as long as the remaining distal segments together and with a rudimentary exopod. The fourth peraeopod is a little longer than the third one; the basis is about two-thirds the length of the remaining distal segments together and with a rudimentary exopod. The fifth peraeopod is four-fifths as long as the fouth one.

The telson is a little longer than the last abdominal segment; the postanal portion is about one-half the length of the telson and provided with two rather long distal spines (about one-third the length of the telson) and two thread-like lateral spines. The peduncle of the uropod reaches the level of the rear end of the telson, about one and one-third the length of the telson and bears five spines on the inner border. The endopod is nearly two-thirds the length of the peduncular segment and three-segmented, each segment with fine spinules on the inner border; the first segment is long and with two lateral spines; the second one is short and bears a lateral spine; the third segment with a lateral spine and a long terminal spine. The exopod is slightly longer than the endopod and with three apical spines, of which the longest one is a little beyond one-half of the length of the exopod.

Young male (length, about $5.0 \mathrm{~mm}$ ): The general features are very like those of the young female. The pseudorostrum is not so upturned as in the young female. The carapace is one-third of the total length of the animal, one and one-fourth the width, which is more than the depth.

The combined length of all the free thoracic segments is a little more than two-thirds the length of the carapace.

The abdomen is much less than one-half the length of the animal. 
The second peduncular segment of the antennule is a little less than the length of the third one, which is somewhat stouter than that of the female.

The antenna is not yet fully developed and its flagellum barely reaches the posterior lower margin of the carapace.

The basis of the third and fourth peraeopods is provided with an exopod, which is not yet fully developed as in the adult.

The telson has two pairs of the lateral spines and two rather long distal spines.

Manca larva (length, about $1.9 \mathrm{~mm}$ ): The armature and patterns of the dorsal surface of the carapace are very like those in young specimens of both sexes. The telson is only furnished with two long distal spines and the peduncle of the uropod without lateral spines on the inner border.

Material: 2 ㅇ, $4 \delta$ ( $1 \delta$ damaged specimen) young; night surface tow-net, St. 19, off Shinryu ; Aug. 17, 1963. 4 manca larvae; night surface tow-net, St. 21, off Tsukushikoi; Aug. 19, 1963.

Remarks: The specimens from Akkeshi Bay may be referred to D. lazarevi Lomakina (Lomakina 1955 a; $1958 \mathrm{~b}$ ), although they show slight differences attributable to the geographical or growth variation. This species is also closely allied to $D$. alaskensis, from which it is distinguishable by the armature of uropod and the pattern of the transverse ridges on carapace.

Distribution: River mouth of Amur (Sea of Okhotsk).

\section{Diastylopsis dawsoni forma calmani DERzHAVIN}

(Fig. 12)

Diastylopsis Calmani Derzhavin 1926, p. 176, Taf. 4.

D. dawsoni forma calmani, Lomakina 1955a, p. 152;1958b, p. 169, fig. 99.

This species was first described as Diastylopsis Calmani by DerzhaviN (1926). Lomakina (1958 a) suggested that D. Calmani was only a forma of $D$. dawsoni $\mathrm{S}_{\text {MITH }}(1880)$ which ranges from Alaska to Californian waters. $D$. dawsoni froma calmani DeRzhavin is very allied to $D$. dawsoni forma typica Smith (Lomakina $1955 \mathrm{a} ; 1958 \mathrm{~b}$ ), but it is distinguished from the last-named forma by providing the round antero-lateral angle with serrations in the female and by having the longer distal spine of the telson (in forma calmani the length of the distal spines of the telson is nearly one-half the length of the telson and in forma typica it is only one-third of the length of the telson).

In general, the body is whitish when alive and the dark brownish contents of the digestive tube are visible through the translucent integument. The cephalic portion is sometimes slightly coloured grayish yellow. The ocular lobe is reddish white, the ocelli are scarcely visible.

Fresh specimens kept in a shallow dish full of the fresh sea water and 
with a thin sand layer on the bottom, swim actively or swiftly burrow in the sand, and sometimes may swim on or hang to the water surface as some crustaceans, such as Tanaidacea, Ostracoda and Amphipoda etc., do.

The specimens from Akkeshi Bay may be identical with D. dawsoni forma calmani with slight differences. This is very abundant in Akkeshi Bay.

Material: 1 juvenile; St. 2, depth $1 \mathrm{~m}$, muddy bottom; Aug. 18, 1963. 1 \% juvenile, 1 manca larva; St. 3, depth $3 \mathrm{~m}$, muddy bottom; Aug. 15, 1963. 13 o young and juvenile, 25 young and juvenile, 77 juvenile and manca larvae; St. 4, depth $8 \mathrm{~m}$, muddy bottom; Aug. 15,

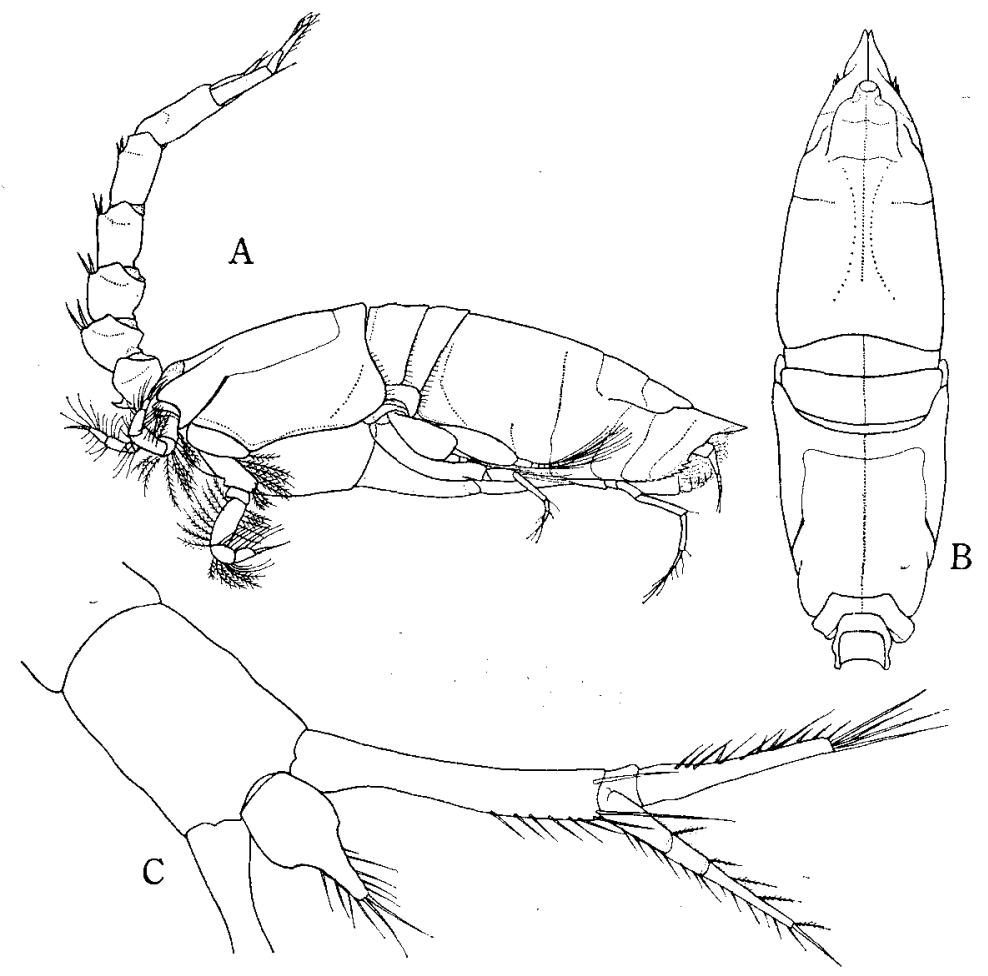

Fig. 12. Diastylopsis dawsoni forma calmani DERzHAviN. Female (length, ca. $14.5 \mathrm{~mm}$ ) : A : lateral view. B : anterior portion of body, from above. $\mathrm{C}:$ telson and uropod with last abdominal segment.

1963. 1 우 adult, 18 우 young and juvenile, 2 \& adult and subadult, 2 s young; St. 5, depth $2 \mathrm{~m}$, sandy bottom; Aug. 18, 1963. 3 ㅇ adult, 2 ㅇ young and juvenile, 7 manca larvae; St. 7, depth $9 \mathrm{~m}$, muddy bottom; Aug. 16, 1963. $9 \%$ adult and subadult, $4 \%$ young and juvenile, $1 \delta$ adult, 6 o young and juvenile; St. 8, depth $11 \mathrm{~m}$, muddy bottom ; Aug. 17, 1963. 20 \% ovigerous, 46 subadult, 34 juvenile, $8 \delta$ subadult, $35 \delta$ young and juvenile, 4 manca larvae; St. 9, depth $11 \mathrm{~m}$, muddy bottom; Aug. 17, 1963. $32 q$ ovigerous and adult, 61 ㅇ young, $5 \uparrow$ adult and subadult, 35 f young, 23 juvenile, 7 manca larvae; St. 10, depth $14 \mathrm{~m}$, sandy mud bottom ; Aug. 17, 1963. 12 adult and subadult, 2 s subadult, 9 juvenile, 39 manca larvae; St. 11-12, sandy and muddy bottom; Aug. 16, 1963. 1 ㅇ adult, 1 o adult; St. 13, depth 6 m, sandy bottom; Aug. 16, 1963. 
9 ㅇ subadult, 4 古 subadult, 1 manca larva; St. 14, depth $13 \mathrm{~m}$, muddy bottom; Aug. 16, 1963. $7 \%$ ovigerous and subadult, $1 \hat{f}$ subadult, 18 juvenile and manca larvae; St. 15, depth $14 \mathrm{~m}$,

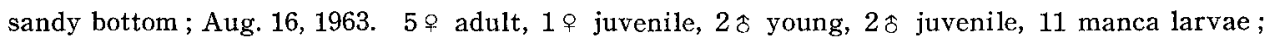
St. 16, depth $15 \mathrm{~m}$, muddy bottom; Aug. 17, 1963. 1 \% subadult, 43 \% young and juvenile, $33 \delta$ young and juvelnie; night surface tow-net, St. 19, off Shinryu; Aug. 17, 1963. 2 o young, 49 \% juvenile, $5 \delta$ young, $67 \delta$ young and juvenile, many juveniles and manca larvae; night surface tow-net, St. 20, off Akkeshi M.B. Station; Aug. 16, 1963. $8 \propto$ young and juvenile, $9 \delta$ young and juvenile, 9 manca larvae; night surface tow-net, St. 20, off Akkeshi M.B. Station; Aug. 19, 1963. $8 \%$ young and juvenile, 10 \& young and juvenile, 97 juvenile; night surface tow-net, St. 21, off Tsukushikoi ; Aug. 16, 1963, 5 ㅇ juvenile, $7 \hat{\delta}$ juvenile, 109 manca larvae; night surface tow-net, St. 21, off Tsukushikoi ; Aug. 19, 1963.

Distribution: Bering Sea, Sea of Okhotsk and northern part of Sea of Japan.

\section{Dimorphostylis asiatica ZIMMER}

Dimorphostylis asiatica ZIMMER 1921, s. 144, Abb. 45-47.

D. asiatica, FAGE 1945, p. 220, fig. 43.

D. asiatica, LoMAKINA $1955 \mathrm{a}$, p. $153 ; 1958 \mathrm{a}$, p. 211 ; 1958b, p. 169, fig. 100.

D. asiatica, GAMô 1960 a, p. 387 ; 1960c, p. 118 , pl. 59 , fig. $9 ; 1962$, p. $200 ; 1963$, p. 59 .

D. asiatica, HARADA 1960, p. 203, fig. 2 .

Materal : 1 manca larva ; St. 2, depth $1 \mathrm{~m}$, muddy bottom ; Aug. 18, 1963. 1 \% subadult ; St. 3, depth $3 \mathrm{~m}$, muddy bottom; Aug. 15, 1963. 4 우 adult with well-developed marsupium, 24 우 subadult, 9 \% juvenile, 3 \& adult, 1 o young, 13 manca larvae ; St. 6 , about $0.3 \mathrm{~m}$ below low water level, fine sandy bottom ; Aug. 19, 1963. 1 manca larva; St. 10, depth $14 \mathrm{~m}$, sandy mud bottom ; Aug. 17, 1963. $8 \delta$; night surface tow-net, St. 19, off Shinryu ; Aug. 17, 1963. $5 \hat{\delta}$; night surface tow-net, St. 20, off Akkeshi M.B. Station; Aug. 16, 1963. 2 manca larvae ; St. 21, off Tsukushikoi, night surface tow-net; Aug. 16 and 19, 1963.

Distribution: Zaliv Petra Velinkogo (Peter the Great Bay), Shikotan Island (Southern Kuril); Sado Island, Shinzi Lake (Tottori Prefecture), Tokyo Bay (Gamô 1963 b), Sagami Bay, Izu Peninsula, Kôchi, Tamano (Okayama Prefecture), Nagasaki, Amami-Oshima; Formosa, Viet-nam.

\section{LITERATURE}

Calman, W. T. 1912. The Crustacea of the order Cumacea in the collection of the United States National Museum. Proc. U. S. Nat. Mus., vol. 41, pp. 603-676, figs. 1-112.

Derzhavin, A. 1923. Malacostraca der Sïßwasser-Gewässer von Kamtchatka. Russ. hydrobiol. Z., ss. 181-194.

1926. The Cumacea of the Kamtchatka Expedition. Ibid., ss. 174-182, Taf. 3-6.

EKMAN, S. 1955. Zoogeography of the Sea. pp. i-xiv, 1-417, figs. 1-121. Sidgwick \& Jackson. London.

FAGE, L. 1954. Les Cumacés du plankton nocturne des côtes d'Annam. Arch. Zool. éxp. et gén., T. 84, pp. 165-224, figs. 1-43.

GaMô, S. 1958. On some species of cumacean Crustacea from Sagami Bay. Zool. Mag. Tokyo, vol. 67 , pp. 383-389, figs. 1-2.

1960a. Five new species of cumacean Crustacea, Genus Dimorphostylis (Diastylidae) from Sagami Bay. Ibid., vol. 69, pp. 101-111, figs. 1-8. 
GAMô, S. 1960b. Cumacea, Encyclopedia Zoologica Illustrated in Colours, vol. IV, p. 118, pl. 59. Hokuryu-kan. Tokyo. (In Japanese).

1962. On the cumacean Crustacea from Tanabe Bay, Kii Peninsula. Publ. Seto Mar. Biol. Lab., vol. 10, pp. 153-210, figs. 1-40.

1963a. On the cumacean Crustacea obtained from Amami-Oshima Island, Southern Japan. Sci. Rep. Yokohama National Univ., sec. 2, no. 10, pp. 29-60, figs. 1-18.

1963b. Review on the order Cumacea, with a list of the species found in Japan.

Researches on Crustacea, no. 1, pp. 73-90, pls. 9-15, figs. 1-3. (In Japanese with short English résumé).

1964a. On some cumacean Crustacea from Sagami Bay, with the description of two new species. Sci. Rep. Yokohama National Univ., sec. 2, no. 11, pp. 17-28, figs. 1-7.

1964b. On three new species of Cumacea from the southern Sea of Japan. Crustaceana, vol. 7, pp. 241-253, figs. 1-7.

1965. On three new species of Cumacea, Crustacea from Akkeshi Bay. Publ. Akkeshi Mar. Biol. Sta., no. 14, pp. 1-21, figs. 1-10.

Harada, I. 1960. Cumacean Fauna of Japan II. Family Diastylidae (Part 1). Genus Dimor. phostylis. Sci. Rep. Tokyo Kyoiku Daigaku, sec. B, vol. 9, pp. 199-225, figs. 1-12.

JoNES, N. S. 1963. The marine fauna of New Zealand; Crustacea of the order Cumacea. Bull. N. Z. Dep. Sci. industr. Res. 152, pp. 1-80, figs. 1-349. (N. Z. Oceanogr. Inst. Mem. No. 23 ).

Lomakina, N. B. 1955a. Cumacea from Far-east seas. Trav. Zool. Acad. Sci. U.S.S.R., T. 18, pp. 112-165, figs. 1-15. (In Russian).

1955b. Cumacea (pp. 125-137, pl. 27) in: Uschakov, P.: Atlas of Invertebrates of the Far East Seas of the U.S.S.R., pp. 1-243, pls. 1-66. U.S.S.R. Acad. Sci. Pbl. House. Moscov. (In Russian).

1958a. Cumacea of the regions of the Kuril-Sakhalin expedition works. Explor.

Far Eastern Seas of U.S.S.R., T. 5, pp. 205-216, figs. 1-2. (In Russian).

1958b. Cumacea of the Seas of U.S.S.R., pp. 1-301, figs. 1-201. U.S.S.R. Acad.

Sci. Publ. House. Moscov. (In Russian).

Pérès, J. M. 1961 . Océanographie biologique et biologie marine. T. 1, pp. 1-541, figs. 1-35. Univ. de France Press. Paris.

Pike, R. B. and R. F. LE SUeur. 1958. The shore zonation of some Jersey Cumacea. Ann. Mag. Hist., ser. 13, vol, 1, pp. 515-523, figs. 1-4.

SARS, G. O. 1900. An account of the Crustacea of Norway, III. Cumacea. pp. $\mathrm{i}-\mathrm{x}, 1-114$, Tafs. 1-69. Christiania.

Stebbing, Th. R. R. 1913. Cumacea (Sympoda). Das Tierreich. Lief. 39, pp. i-xvi. 1-210, figs. 1-173. Berlin.

Uchida, T., M. Yamada, F. Iwata, Ch. OGuro and Z. NAgao. 1963. Zoological Environs of the Akkeshi Marine Biological Station. Publ. Akkeshi Mar. Biol. Sta., no. 13, pp. 1-36, pls. 1-4, figs. 1-7.

UÉNO, M. 1933. Inland waters fauna of the North Kurile Islands. Bull. biogeogr. Soc. Tokyo, vol. 4, pp. 171-212, figs. 1-18, pls. 15-18.

241-246.

YAMAZI, I. 1950. Plankton investigation in inlet waters along the coast of Japan. I. Introductory notes and the plankton of Akkeshi Bay, Hanasaki Inlet and Nemuro Harbour. Publ. Seto Mar. Biol. Lab., vol. 1, pp. 93-112, figs. 1-14.

ZenkevitCh, L. 1963. Biology of the Seas of the U.S.S.R., pp. 1-995, figs. 1-841. George Allen \& Unwin. London.

Zimmer, C. 1903. Die Cumaceen des Museums für Naturkunde in Berlin. Zool. Jahrb., Syst., Bd. 18, ss. 665-694, Abb. A-Z, AA-EE. 
ZIMMER, C. 1921. Mitteilungen über Cumaceen des Berliner Zoologischen Museums. Mitt. Zool. Mus. Berlin, Bd. 10, ss. 117-149, Abb. 1-55.

1929. Einige Cumaceen aus russischen Meeren. Expl. Mers. URSS, fasc. 9, ss. 61-69, Abb. 1-5.

1930. Untersuchungen an Dastyliden (Ordnung Cumacea). Mitt. zool. Mus. Berlin, Bd. 16, ss. 583-658, Abb. 1-47.

1939. Pazifischen Cumaceen. Expl. Mers URSS. fasc. 23, ss. 38-54, Abb. 1-17.

1940. Die Verbreitung der Cumaceen. Arch. Naturg., (2) Bd. 9, ss. 224-313,

Abb. 1-2.

1941. Cumaceen. in : BroNN's Klassen u. Ordnungen des Tierreich. Bd. 5, Abt. 1, Buch 4, ss. 1-222, Abb. 1-226. Akad. Verlangs. Leipzig.

1943. Cumaceen des Stillen Ozeans. Arch. Naturg. Leipzig, (N. F.) Bd. 12, ss. 130-174, Abb. 1-61. 